Marquette University Law School

Marquette Law Scholarly Commons

Faculty Publications

Faculty Scholarship

$1-1-2008$

\title{
Whither the Pickering Rights of Federal Employees?
}

Paul M. Secunda

Marquette UniversityLaw School, paul.secunda@marquette.edu

Follow this and additional works at: http://scholarship.law.marquette.edu/facpub

Part of the Law Commons

Publication Information

Paul M. Secunda, Whither the Pickering Rights of Federal Employees?, 79 U. Colo. L. Rev. 1101 (2008). Reprinted with permission of the University of Colorado Law Review and the author.

\section{Repository Citation}

Secunda, Paul M., "Whither the Pickering Rights of Federal Employees?" (2008). Faculty Publications. Paper 592.

http://scholarship.law.marquette.edu/facpub/592

This Article is brought to you for free and open access by the Faculty Scholarship at Marquette Law Scholarly Commons. It has been accepted for inclusion in Faculty Publications by an authorized administrator of Marquette Law Scholarly Commons. For more information, please contact 


\title{
WHITHER THE PICKERING RIGHTS OF FEDERAL EMPLOYEES?
}

\author{
PAUL M. SECUNDA*
}

As a result of the Supreme Court's 1983 decision in Bush v. Lucas, federal employees are not permitted to bring Bivens constitutional tort claims directly to federal court to vindicate their First Amendment rights to free speech under Pickering v. Board of Education. Instead, the Bush Court found that Congress had established an effective, alternative statutory scheme for vindication of such claims under the Civil Service Reform Act of 1978. This places federal employees in a less favorable predicament than their state and local employee counterparts who are able to directly proceed to court on their First Amendment retaliation claims under 42 U.S.C. $\$ 1983$.

The issue examined in this paper for the first time is whether the alternative remedy of bringing a First Amendment Pickering claim to an administrative judge designated by the Merit Systems Protection Board, and then potentially to the Board itself, and finally to the Federal Circuit Court of Appeals, provides meaningful redress for federal employees with First Amendment Pickering claims. An empirical analysis of all First Amendment Pickering cases decided by the Merit Systems Protection Board and the Federal Circuit leads to a startling finding: an online search has not located one successful federal employee Pickering claim under the administrative scheme since the Bush decision in 1983. My conclusion is that because there is a lack of meaningful redress, Bush v. Lucas should be revisited and overturned, and a Bivens claim should be implied to vindicate the First Amendment interests of federal employees.

* Associate Professor of Law, Marquette University Law School. I would like to thank Cindy Estlund, Bill Herbert, Jeff Hirsch, Elaine Mittleman, Jack Preis, Ross Runkel, and Joe Slater, for providing me with their thought-provoking comments and questions on the arguments in this paper. I would also like to thank the feedback I received on this paper at presentations at Colorado, Cumberland, and Seton Hall Law Schools. Of course, all errors or omissions are mine alone. This Article was selected for the 2007 Seton Hall Employment \& Labor Law Scholars' Forum. 


\section{INTRODUCTION}

"The importance of Government employees' being assured of their right to freely comment on the conduct of Government, to inform the public of abuses of power and of the misconduct of their superiors, must be self-evident in these times."

Federal employees lack a meaningful remedy for violations of their Pickering rights ${ }^{2}$ under the First Amendment. Twentyfive years after the United States Supreme Court unanimously decided Bush v. Lucas ${ }^{3}$ and held that federal employees could not bring a Bivens claim ${ }^{4}$ against federal officials for violations of First Amendment free speech rights, the time has come to revisit the logic of that decision.

The predicate behind Bush was that federal employees had an effective alternative remedy for their First Amendment claims under the comprehensive framework of the Civil Service Reform Act of 1978 ("CSRA of 1978"), 5 and therefore it was unnecessary to directly imply a cause of action under the Constitution. ${ }^{6}$ The Bush Court concluded that "claims [that] arise out of an employment relationship that is governed by comprehensive procedural and substantive provisions giving meaningful remedies against the United States" do not give rise to "a new judicial remedy" under the Constitution. ${ }^{7}$

Under the CSRA of 1978 administrative scheme, federal employees must jump through many hoops before being able to

1. Arnett v. Kennedy, 416 U.S. 134, 228 (1974) (Marshall, J., dissenting).

2. "Pickering rights" refer to public employee First Amendment rights to speech, expression, and association. See Pickering v. Bd. of Educ., 391 U.S. 563, 568 (1968) (providing First Amendment speech rights to public employees under framework designed to balance employees' constitutional rights with public employers' efficiency interests).

3. 462 U.S. 367 (1983).

4. "Bivens claims" are "judicially created damages remed[ies] designed to vindicate violations of constitutional rights by federal actors." Hall v. Clinton, 235 F.3d 202, 204 (4th Cir. 2000) (citing Bivens v. Six Unknown Named Agents of Fed. Bureau of Narcotics, 403 U.S. 388, 395-97 (1971)).

5. Pub. L. No. 95-454, 92 Stat. 1111 (codified as amended in scattered sections of 5 U.S.C.).

6. The Court also concluded in Bush that special factors involving Congress' institutional competence in dealing with federal employment relations counseled hesitation in implying a constitutional judge-made remedy. Bush, 462 U.S. at 388-90. For reasons further developed below, I also argue that there are no longer "special factors counseling hesitation" that would prevent implying a Bivens right in the federal employment free speech context. See infra Part IV.A.

7. Bush, 462 U.S. at 368. 
have their constitutional claims reviewed by an Article III court. They must first file their initial appeal of an agency decision with an administrative law judge ("AJ") designated by the Merit Systems Protection Board ("MSPB"), then file a petition for review with the MSPB, before finally appealing to the Federal Circuit Court of Appeals. ${ }^{8}$ Even when an Article III court finally hears the claim, it is heard under a highly deferential standard of review that has historically led to an astronomical affirmation rate of ninety-three to ninety-six percent. ${ }^{9}$

Given this convoluted process, perhaps it is not surprising that the MSPB administrative scheme is not vindicating the First Amendment Pickering rights of federal employees. ${ }^{10}$ But the extent of the problem is truly extraordinary. A first-time comprehensive analysis of all MSPB Board ${ }^{11}$ and Federal Circuit cases involving federal employees' First Amendment Pickering claims leads to a startling discovery: not a single First Amendment Pickering claim filed by a federal employee against the employee's agency has ever been successful on the merits before either of these adjudicatory bodies. ${ }^{12}$ Additionally,

8. See infra Part III.B.

9. See infra Part III.C.

10. Developments in the Law-Public Employment, 97 HARV. L. REV. 1611, 1635-36 (1984) ("Yet although the [MSPB] has assumed the trappings of judicial power, a review of the major dimensions of the Board's jurisprudence-including access to the Board, the standards of review it employs, the remedial powers it wields, and the reviewability of its decisions in the federal courts-reveals a marked disposition to circumscribe the protections afforded federal employees.").

11. It is most likely true that some First Amendment Pickering claims have been successful in front of administrative judges designated by the MSPB to hear most initial appeals of federal agency personnel decisions. See infra Part III.A. However, these decisions are not reported and have no precedential value. See ROBERT G. VAUGHN, MERIT SYSTEMS PROTECTION BOARD: RIGHTS \& REMEDIES $\S$ 5.01, at 5-2 (rev. ed. 2008) (1984) (citing Horner v. Burns, 793 F.2d 196, 201 (Fed. Cir. 1986)). Consequently, it is unclear how successful federal employees have been in these cases overall, but one would think that agencies would frequently appeal from adverse decisions at the AJ level. One other statistic making it unlikely that there are many of these cases is the fact that eighty-eight percent of petitions for review from the AJ level to the MSPB are by employees appealing adverse decisions. See id.

12. See infra Part III.B, C. Contrariwise, although some commentators have called success rates under similar constitutional claims against state and local officials under Section 1983 "dismal," see Stephen W. Dummer, Comment, Secure Flight and Data Veillance, A New Type of Civil Liberties Erosion: Stripping Your Rights When You Don't Even Know It, 75 Miss. L.J. 583, 596 n.63 (2006), there are still plenty of examples of state and local employees prevailing on their First Amendment claims under Section 1983. For instance, in a study of 1980-1981 filings in the Central District of California, the Eastern District of Pennsylvania, and the Northern District of Georgia by Professors Schwab and Eisenberg, the average success rate for all civil rights actions (excluding employment discrimina- 
the number of First Amendment appeals is notably low. ${ }^{13}$ The message that federal employees seem to be receiving is that their First Amendment claims will not be treated seriously. Employees are instead left to bring largely ineffective statutory whistleblowing claims ${ }^{14}$ or swallow hard. Such a state of affairs diminishes the ability of courts to protect federal employees' rights using constitution law ${ }^{15}$ and indicates that the agency and court entrusted to decide these cases lack the necessary neutral competence.

It is somewhat puzzling that federal employees find themselves in this predicament. At first blush, it would seem that federal employees are endowed with the same free speech pro-

tion actions) was thirty percent. Theodore Eisenberg \& Stewart Schwab, The Reality of Constitutional Tort Litigation, 72 CORNELL L. REV. 641, 690-91 (1987).

13. There are only twenty-some MSPB decisions and ten Federal Circuit decisions in the last twenty-five years on First Amendment Pickering claims. See infra notes 255-57 and accompanying text. There are likely thousands of such constitutional tort claims under Section 1983 in any given year. Eisenberg \& Schwab, supra note 12, at 655 (finding 468 Section 1983 cases in the Central District of California in 1981 alone).

14. Federal employees' whistleblowing claims are brought under the Whistleblower Protection Act of 1989 ("WPA"), Pub. L. No. 101-12, 103 Stat. 16 (codified at 5 U.S.C. $\S \S 1211-1219,1221,1222,3352(2000))$. WPA claims have been highly unsuccessful. See Terry Morehead Dworkin, SOX and Whistleblowing, $105 \mathrm{MICH}$. L. REV. 1757, 1766 (2007) ("Among other signs of failure, only one of the 120 appeals brought by whistleblowers to the Federal Circuit Court of Appeals-the designated recipient-has been successful since 1984."); Barbara J. Sapin, Beyond Garcetti, The Limits of Protection Under the Whistleblower Protection Act of 1989, in RETAliation AND Whistleblowing: PROCEEDINGS OF NEW YORK UNIVERSiTY 60Th AnNual Conference on Labor (Paul M. Secunda ed., forthcoming Sept. 2008) (current MSPB Board Member exploring the limits of WPA protection for federal employees); Jamie Sasser, Comment, Silenced Citizens: The Post-Garcetti Landscape for Public Sector Employees Working in National Security, 41 U. RICH. L. REV. 759, 790 (2007) ("Public sector employees simply cannot rely on whistleblower statutes to save them. From 1999 to 2005, only two out of thirty whistleblower claims prevailed before the Merit Systems Protection Board; from 1995 to 2005, only one out of ninety-six claims prevailed before the Federal Circuit."); Stephen Barr, Speaking Up for the Whistle-Blowers, WASH. POST, Feb. 14, 2007, at D1 ("Although Congress has passed laws to protect federal employees from reprisals when they speak up, whistle-blower advocates contend that the U.S. Court of Appeals for the Federal Circuit, which has sole jurisdiction over federal whistleblower cases, has interpreted the laws in a way that makes it almost impossible for federal employees to defend themselves."); $c f$. William A. Herbert, Protection for Public Employees Who "Blow the Whistle" Appear to be Inadequate, N.Y. B. J., Feb. 2004, at 20-29 (analyzing similar inadequacies with New York's public sector statutory whistleblower scheme).

15. See Davis v. Passman, 442 U.S. 228, 242 (1979) ("[U]nless [constitutional] rights are to become merely precatory, ... litigants who allege that their own constitutional rights have been violated, and who at the same time have no effective means other than the judiciary to enforce these rights, must be able to invoke the existing jurisdiction of the courts for ... protection . ..."). 
tections as state and local public employees under the First Amendment. Under Pickering $v$. Board of Education, ${ }^{16}$ government workers may not be terminated for criticizing their employers on matters of public concern, ${ }^{17}$ unless such expression is uttered pursuant to official duties ${ }^{18}$ or substantially interferes with the ability of the government employer to provide an efficient service to the public. ${ }^{19}$ Justice Marshall set forth the applicable test in Pickering: "The problem in any case is to arrive at a balance between the interests of the [public employee], as a citizen, in commenting upon matters of public concern and the interest of the State, as an employer, in promoting the efficiency of the public services it performs through its employees." 20

Pickering and its progeny state no exception or special treatment for federal employees. ${ }^{21}$ Indeed, in United States $v$. National Treasury Employees Union ("NTEU"),22 the Supreme Court held that federal employees could not, pursuant to the logic of Pickering, be prohibited from receiving honoraria for engaging in speech of a public concern on matters unrelated to their employment. ${ }^{23}$ The Supreme Court recently reaffirmed the validity of its NTEU holding in its City of San Diego $v$. Roe per curiam decision. ${ }^{24}$ Moreover, the recent scaling back of Pickering's central holding by Connic v. Myers' public concern test $^{25}$ and Garcetti v. Ceballos'official duties test ${ }^{26}$ does not indicate that a distinction should be drawn between the First Amendment rights, whatever their scope, of federal employees and other types of public employees.

Of course, there is a significant procedural difference between how federal and state employees may bring such First

16. 391 U.S. 563 (1968).

17. See Connick v. Myers, 461 U.S. 138, 154-55 (1983).

18. See Garcetti v. Ceballos, 547 U.S. 410, 426 (2006).

19. Pickering, 391 U.S. at 568.

20. Id.

21. Indeed, the three-judge plurality opinion in Arnett v. Kennedy indicates that the Pickering balance applies equally to speech claims of federal employees. 416 U.S. 134, 160-61 (1974) (plurality opinion).

22. 513 U.S. 454 (1995).

23. Id. at $468-70$.

24. 543 U.S. 77, 81 (2004) (per curiam) (holding that a police officer who sold explicit videos of himself on eBay did not engage in expression on a matter of public concern and did not qualify for First Amendment protection).

25. Connick v. Myers, 461 U.S. 138, 147-48 (1983). See infra notes $44-49$ and accompanying text.

26. Garcetti v. Ceballos, 547 U.S. 410, 421-422 (2006). See infra notes 37-43 and accompanying text. 
Amendment claims. While state and local employees clearly have the procedural vehicle of $\S 1983^{27}$ to bring constitutional claims against state and local government employers, federal employees have no such available statutory claim. ${ }^{28}$ Nevertheless, there does not appear to be a good argument for why federal employees should receive different remedies and procedures from their state and local employee counterparts, for the same unconstitutional conduct. ${ }^{29}$ Indeed, in a related context, the Court argued for parallel treatment of state and federal employees who violate the constitutional rights of others, recognizing "sound jurisprudential reasons for parallelism, as different standards for claims against state and federal actors 'would be incongruous and confusing.' "30

Consequently, because the administrative scheme set up for federal employee First Amendment speech claims does not provide meaningful remedies, and there is no sound argument why federal employees should have less free speech rights than state and local employees, an implied Bivens right should be resurrected in these cases. ${ }^{31}$ Such protections will not only benefit employees, but all citizens who depend on public employees to bring a substantial degree of transparency and accountability to our representative government. ${ }^{32}$

27. Civil Rights Act of 1871,42 U.S.C. $\$ 1983$ (2000). See infra notes $62-74$ and accompanying text.

28. See Martin A. Schwartz, Claims for Damages for Violations of State Constitutional Rights-Analysis of the Recent Court of Appeals Decision in Brown v. New York; The Resolved and Unresolved Issues, 14 TOURO L. REV. 657, 660 (1998) ("Section 1983 only covers actions under color of state law; of course, federal officials act under color of federal law.").

29. Federal employees and state employees apparently have the same Fourth Amendment rights to be free from unreasonable search and seizure in the drug testing context. See Nat'1 Treasury Employees Union v. Von Raab, 489 U.S. 656, 677 (1989) (concluding that the immediacy of the government's concern and the minimal nature of the intrusion outweighed the individual's privacy interest and permitted the government to drug test federal customs agents).

30. Corr. Servs. Corp. v. Malesko, 534 U.S. 61, 82 (2001) (Stevens, J., dissenting) (quoting Butz v. Economou, 438 U.S. 478, 499 (1978)).

31. One could argue that because federal courts have traditionally protected individual's constitutional rights, they should be given greater latitude in implying causes of action under the Constitution. See Bivens v. Six Unknown Named Agents of Fed. Bureau of Narcotics, 403 U.S. 388, 407 (1971) (Harlan, J., concurring) ("[T]he judiciary has a particular responsibility to assure the vindication of constitutional interests . . .."). But see Wilkie v. Robbins, 127 S. Ct. 2588, 2608 (2007) (Thomas, J., concurring) ("Bivens is a relic of the heady days in which this Court assumed common-law powers to create causes of action." "(quoting Malesko, 534 U.S. at 75 (Scalia, J., concurring))).

32. See supra note 1 and accompanying quotation. 
This Article proceeds in four parts. Part I lays out the new, post-Garcetti five-step analysis for public employees' Pickering rights. Part II briefly examines the history of Bivens jurisprudence. The emphasis in this Part is on the Court's conclusion that there is no Bivens right for federal employees claiming First Amendment Pickering violations as a result of there being effective, alternative remedies for First Amendment claims under the CSRA of 1978. Part III explores whether federal employees are in fact receiving meaningful redress under the CSRA of 1978 by examining in detail all First Amendment Pickering appeals before the MSPB and the Federal Circuit. Because that analysis clearly establishes a lack of a meaningful remedy, Part IV proposes overturning Bush and permitting Bivens claims in this context so that employees can adequately vindicate their First Amendment rights. Alternatively, $\S 1983$ could be amended to additionally cover constitutional violations "under color of federal law."33

\section{The FiRst AmENDMENT PICKERING Rights OF PUBLiC EMPLOYEES: THE FREE SPEECH FIVE-STEP}

All public employees, whether state or federal, enjoy some measure of First Amendment protection. Since the 1968 case of Pickering $v$. Board of Education, ${ }^{34}$ the government, acting in its employment capacity, has not been able to condition employment on workers forfeiting their constitutional rights. ${ }^{35}$ Instead, the United States Supreme Court has implicitly asked whether the restrictions placed by government employers on their employees are reasonable under all the circumstances. ${ }^{36}$

The reasonableness of a public employer's response to public employee speech involves a complicated five-step analysis. The first step, after the recent case of Garcetti $v$. Ceballos, ${ }^{37}$ is

33. Richard Henry Seamon, U.S. Torture as a Tort, 37 RUTGERS L.J. 715, 759 (2006) (proposing, in the national security context, a federal statute that would be identical to Section 1983 except that it would apply to persons acting under federal law).

34. 391 U.S. 563 (1968).

35. Id. at 568 .

36. See Jonathan C. Medow, The First Amendment and the Secrecy State: Snepp v. United States, 130 U. PA. L. REV. 775, 816 (1982) ("Implicit in Pickering seems to be a determination that 'reasonableness' is the standard by which to judge the conditioning of public sector employment on a relinquishment of some measure of first amendment rights.").

37. 547 U.S. 410 (2006). For a more in-depth discussion of Garcetti and its facts, see Paul M. Secunda, Garcetti's Impact on the First Amendment Speech 
to ask whether the employee is speaking pursuant to official duties. ${ }^{38}$ In determining what the employee's official duties are, "[t]he proper inquiry is a practical one" and should focus on "the duties an employee actually is expected to perform."39 If employees are engaged in official duty speech at work, the Court has held that they are not speaking as citizens and thus enjoy no First Amendment protection for their speech. ${ }^{40} \mathrm{Al}$ though post-Garcetti litigation is still in its nascent stages, it appears that much of the litigation will focus on a practical assessment of what the public employee's official duties are, with employers seeking broad definitions and employees more narrow ones. ${ }^{41}$ The only thing that is apparently clear concerning the job-relatedness of speech is that public employee speech that occurs off-duty and is not work-related (anti-Garcetti speech) does not come under the Pickering framework at all. Rather, under the NTEU line of cases, ${ }^{42}$ it is protected much like normal citizen speech. ${ }^{43}$

Rights of Federal Employees, 7 FiRST AMEND. L. REV., (forthcoming 2008).

38. Id. at 421 ("[W] hen public employees make statements pursuant to their official duties, the employees are not speaking as citizens for First Amendment purposes, and the Constitution does not insulate their communications from em. ployer discipline.").

39. Id. at $424-25$.

40. Id. Interestingly, this holding that government workers cannot act as employees and citizens at the same time controverts a previous statement of the Court that a teacher making a presentation before a board of education "spoke both as an employee and a citizen exercising First Amendment rights." City of Madison Joint Sch. Dist. No. 8 v. Wis. Employment Relations Comm'n, 429 U.S. 167, 176 n.11 (1976).

41. See, e.g., Morales v. Jones, 494 F.3d 590, 596 (7th Cir. 2007) (citing Haynes v. City of Circleville, Ohio, 474 F.3d 357 (6th Cir. 2007)); Mayer v. Monroe County Cmty. Sch. Corp., 474 F.3d 477 (7th Cir. 2007); Green v. Bd. of County Comm'rs, 472 F.3d 794 (10th Cir. 2007); Freitag v. Ayers, 468 F.3d 528 (9th Cir. 2006); Battle v. Bd. of Regents for the State of Ga., 468 F.3d 755 (11th Cir. 2006); Mills v. City of Evansville, 452 F.3d 646 (7th Cir. 2006) (reviewing cases postGarcetti that have examined the scope of an employee's duties from a practical perspective). For a trenchant criticism of this approach, see Charles W. Rhodes, Public Employee Speech Rights Fall Prey to an Emerging Doctrinal Formalism, 15 WM. \& MARY BILL RTS. J. 1173, 1193-94 (2007) ("Although the result may be predictable in cases in which it is undisputed that the speech was made pursuant to the employee's official duties, the Court has merely shifted the uncertainty to the scope of the underlying categorization. Rather than the relatively stable balancing process that had become familiar in these cases, the lower courts are now confronted with an inexact classification prerequisite that is already generating unpredictable results.").

42. United States v. Nat. Treasury Employees Union (NTEU), 513 U.S. 454, 465,475 (1995).

43. "[W] hen government employees speak or write on their own time on topics unrelated to their employment, the speech can have First Amendment protection, absent some governmental justification 'far stronger than mere speculation' in 
Second, if the employee can show that he or she is not speaking pursuant to official duties, the next step in the framework concerns whether the employee is speaking out on a matter of public concern. Under Connick v. Myers ${ }^{44}$ courts are directed to look at the surrounding content, form, and context of the speech to see if the speech involves a matter of public concern. ${ }^{45}$ This type of speech "typically [includes] matters concerning government policies that are of interest to the public at large, a subject on which public employees are uniquely qualified to comment." 46 Sometimes courts ask whether the speech addresses a "matter of political, social, or other concern to the community," 47 or is worthy of legitimate news interest. 48 If the court determines that the speech merely involved purely private interests, like an employment dispute with one's supervisors, then there is no First Amendment protection for the speech, because it does not implicate the core concerns of the First Amendment. 49

Third, if the speech relates to a matter of public concern not connected to a public employee's official duties, a court then undertakes a Pickering balance of interests test. Under this

regulating it." City of San Diego v. Roe, 543 U.S. 77, 80 (2004) (per curiam) (quoting NTEU, 513 U.S. at 465, 475). See also Cynthia L. Estlund, Free Speech Rights That Work at Work: From the First Amendment to Due Process, 54 UCLA L. REv. 1463, 1468 (2007) ("City of San Diego, and its reading of NTEU, appear to place an outer limit on the additional power of the government over the speech of its employees. While that outer limit is a bit further from the workplace than one might have expected, at some point along the spectrum of work-relatedness, the public employee apparently escapes the Connick-Pickering niche and recovers her freedom as a citizen vis-à-vis the government."). Professor Estlund also provides a very helpful diagram outlining the contours of public employee speech postGarcetti. Id. at 1470.

44. 461 U.S. 138 (1983). For an in-depth consideration of the background in Connick, see Paul M. Secunda, The (Neglected) Importance of Being Lawrence: The Constitutionalization of Public Employee Rights to Decisional Non. Interference in Private Affairs, 40 U.C. DAVIS L. REV. 85, 99-102 (2006).

45. Connick, 461 U.S. at 147-48.

46. City of San Diego, 543 U.S. at 80.

47. Connick, 461 U.S. at 146-47.

48. City of San Diego, 543 U.S. at 83-84. The Court itself has recognized, however, that, "the boundaries of the public concern test are not well defined." Id. at 83 . Past cases provide the best indication about whether speech pertains to a matter of public concern.

49. Connick, 461 U.S. at 147. Nevertheless, the speech does not have to be publicly disseminated. Private conversations on matters of public concern may be protected under the First Amendment. See Rankin v. McPherson, 483 U.S. 378, 388 n.13 (1987) (recognizing that private, negative comments about the President can touch on matters of public concern); Givhan v. W. Line Consol. Sch. Dist., 439 U.S. 410, 415-16 (1979) (private conversation between school teacher and principal on racial discrimination at the school was on a matter of public concern). 
balancing test, first developed in the public school teacher case of Pickering, ${ }^{50}$ a court weighs the First Amendment interests of the employee as a citizen against the government interest in running an efficient government service for the public. ${ }^{51}$ Here, courts place much emphasis on whether the employee's speech causes a substantial disruption in the workplace..$^{52}$ Courts measure substantial disruption, in turn, on such things as "the impact of the speech on working relationships, the harm caused by the speech, the public's interest in the speech, and the employee's relationship to that issue."53 Paradoxically, this substantial disruption standard appears to constitutionalize the heckler's veto and makes most vulnerable that speech which is the most unpopular and warrants the most protection under the First Amendment. ${ }^{54}$ If the balance under Pickering favors the government, the public employee has no First Amendment rights in the speech.

Fourth, if the Pickering balance favors the employee, the court considers the employee to have engaged in protected speech. Next, under the evidentiary framework established in Mount Healthy City School District v. Doyle, ${ }^{55}$ the employee must prove by a preponderance of the evidence that engaging in the protected speech was a substantial or motivating factor for the adverse employment action the employee suffered. ${ }^{56}$

Fifth, and finally, if the employee satisfies the causation standard in step four, the government then has the burden of persuasion to show that it would have made the same decision even in the absence of the protected employee speech. ${ }^{57}$ If the public employer is successful in meeting this burden, there is no liability. This is because "[t]he constitutional principle at stake is sufficiently vindicated if such an employee is placed in no worse a position than if he had not engaged in the conduct." 58 Only if the employee can survive this fifth and last ob-

50. 391 U.S. 563 (1968).

51. Id. at 568 .

52. Randy J. Kozel, Reconceptualizing Public Employee Speech, 99 NW. U. L. REV. 1007, 1018 (2005).

53. Rhodes, supra note 41 , at 1177.

54. Kozel, supra note 52, at 1018.

55. 429 U.S. 274 (1977).

56. Id. at 287 .

57. Id.

58. Id. at $285-86$. 
stacle may liability be imposed against the public employer and the employer's responsible agents. ${ }^{59}$

\section{SECTION 1983 AND THE BIVENS DoCTRINE}

As complicated as the framework is in public employee free speech cases, in all of these cases the Court consistently used the term "public employee" to refer to the First Amendment rights of the employees in question. No distinction was made between whether the employee was a state or federal employee. Nevertheless, even though the rights should be the same, the process by which the rights are vindicated and the remedies which are available, and against whom, turn out to be different for federal and state employees.

The first part of this section describes the distinction between the constitutional rights of federal employees and state and local employees. The second part of this section describes the implied constitutional remedy that exists against federal agents under the Bivens line of cases. Finally, the last part explains how Bush $v$. Lucas prevents federal employees from bringing First Amendment claims against their employers under Bivens.

\section{A. The Section 1983 Distinction}

Plaintiffs brought most of the public employment free speech cases discussed in the previous section pursuant to the Civil Rights Act of 1871, now referred to by its place in the U.S. Code, $\S 1983 .{ }^{60}$ To bring a $\S 1983$ claim, a plaintiff must show

59. But even then, state employers may be able to avail themselves of sovereign immunity under the Eleventh Amendment, and responsible agents of the employers may be able to avoid individual damages liability if they show they are eligible for qualified immunity, though they may still be subject to injunctive relief. See ERWIN CHEMERINSKY, FEDERAL JURISDICTION $§ 8.6 .3$, at 529 (4th ed. 2003) ("Qualified immunity exists only as to suits for damages, not as to suits for injunctive relief."). Qualified immunity is applicable if a reasonable person would not have known that his or her conduct violated clearly established constitutional rights. Harlow v. Fitzgerald, 457 U.S. 800, 818 (1982) ("[G]overnment officials performing discretionary functions[] generally are shielded from liability for civil damages insofar as their conduct does not violate clearly established statutory or constitutional rights of which a reasonable person would have known."). See also infra Part III.A.

60. 42 U.S.C. $§ 1983$ (2000) ("Every person who, under color of any statute, ordinance, regulation, custom, or usage, of any State . . subjects, or causes to be subjected, any citizen of the United States or other person within the jurisdiction thereof to the deprivation of any rights, privileges, or immunities secured by the 
that there was a deprivation of a federally guaranteed right and that the defendant was acting "under color of" state law. ${ }^{61}$ Section 1983 is not substantive; it merely provides a procedural vehicle for plaintiffs to bring constitutional claims against state and local officials. ${ }^{62}$ The purpose of such claims is to "vindicate constitutional rights and deter violations through suits brought by injured persons to stop government illegality and to obtain damages for injuries already suffered."63

Section 1983 claims can be brought directly in federal court $^{64}$ against institutions acting under color of state law or individuals acting in their official or individual capacities. ${ }^{65}$ However, there is no respondeat superior liability under $\S$ $1983 .{ }^{66}$ Consequently, institutional claims are limited to situations where a plaintiff proves a causal link between the institutional policy or custom of the state actor and the plaintiff's injury. ${ }^{67}$ Even then, sovereign immunity under the Eleventh Amendment bars plaintiffs from collecting money damage claims against state institutions in most situations. ${ }^{68}$ Although

Constitution and laws, shall be liable to the party injured in an action at law, suit in equity, or other proper proceeding for redress ....").

61. Id. As far as what constitutes action under state law in the public employment context, the critical inquiry is "whether the [public employee] was acting pursuant to the power he/she possessed by state authority or acting only as a private individual." Edwards v. Wallace Cmty. Coll., 49 F.3d 1517, 1523 (11th Cir. 1995) (citing Monroe v. Pape, 365 U.S. 167, 184 (1961)). Generally, this is not an issue in employment cases, as "state employment is generally sufficient to render the defendant a state actor." Lugar v. Edmondson Oil Co., 457 U.S. 922, 936 n.18 (1982).

62. See Paul M. Secunda, At the Crossroads of Title IX and a New "IDEA": Why Bullying Need Not Be "A Normal Part of Growing Up" for Special Education Children, 12 DUKE J. GENDER L. \& POL'Y 1, 21-22 (2005) (citing Chapman v. Houston Welfare Rights Org., 441 U.S. 600, 617 (1979)).

63. Michael L. Wells, Section 1983, The First Amendment, and Public Em. ployee Speech: Shaping the Right to Fit the Remedy (and Vice Versa), 35 GA. L. REV. 939, 944 (2001).

64. There is no requirement of exhaustion of state judicial remedies under Section 1983. See Steffel v. Thompson, 415 U.S. 452, 472-73 (1974).

65. Monell v. Dep't. of Soc. Servs., 436 U.S. 658, 690 (1978). Actions against individuals in their official capacities are handled under the same standards that apply to actions against institutions. See Kentucky v. Graham, 473 U.S. 159, 165 (1985) (citing Monell, 436 U.S. at 690 n.55).

66. Monell, 436 U.S. at 691-93.

67. Id. at 694 .

68. Will v. Mich. Dept. of State Police, 491 U.S. 58, 66 (1989) ("Section 1983 provides a federal forum to remedy many deprivations of civil liberties, but it does not provide a federal forum for litigants who seek a remedy against a State for alleged deprivations of civil liberties. The Eleventh Amendment bars such suits unless the State has waived its immunity or unless Congress has exercised its undoubted power under $\S 5$ of the Fourteenth Amendment to override that immu- 
this makes it difficult to recover damages against state employers for constitutional violations, local government employers generally do not fall under the Eleventh Amendment and may still be sued for monetary relief. ${ }^{69}$

On the other hand, individual defendants in $\S 1983$ cases may assert a qualified immunity defense to damage claims. ${ }^{70}$ Under this theory, individual state and local officials are only liable if a reasonable official would have known that he or she was violating a constitutional standard that was "clearly established at the time" of the action. ${ }^{71}$ Even if qualified immunity is available, however, a $\S 1983$ plaintiff can still receive injunctive relief against the targeted state or local official. ${ }^{72}$ Prevailing plaintiffs may also be entitled to attorneys' fees under $\S 1988 .{ }^{73}$

No statute similar to $\S 1983$ exists for constitutional violations against federal employees and their agencies. ${ }^{74}$ This is

nity.") (citation omitted).

69. Monell, 436 U.S. at $690 \&$ nn.53-54 (holding that a municipality is a "person" under Section 1983, and therefore local government units that are not considered part of the State are not able to take advantage of Eleventh Amendment immunity). Local governments are not entitled to a qualified immunity defense when damages are sought against them, see Owen v. City of Independence, 445 U.S. 622,638 (1980), but may not be sued for punitive damages, see City of New. port v. Fact Concerts, Inc., 453 U.S. 247, 258-70 (1981). Punitive damages are also very hard to recover in the First Amendment retaliation context against individual defendants. See Wells, supra note 63, at 974-75 ("Punitive damages are rarely available in First Amendment retaliation cases, for they may be awarded only where the defendant's conduct was highly improper.").

70. See Scheuer v. Rhodes, 416 U.S. 232, 247-48 (1974).

71. Harlow v. Fitzgerald, 457 U.S. 800, 818-19 (1982).

72. "Of course a state official in his or her official capacity, when sued for injunctive relief, would be a person under $\S 1983$ because 'official-capacity actions for prospective relief are not treated as actions against the State." Will, 491 U.S. at 71 n.10 (quoting Kentucky v. Graham, 473 U.S. 159, 167 n.14 (1985); Ex parte Young, 209 U.S. 123, 159-60 (1908)).

73. Civil Rights Attorney's Fees Act of 1976, 42 U.S.C. $\S 1988$ (2000). The Eleventh Amendment does not bar recovery of attorney's fees from the state itself. Hutto v. Finney, 437 U.S. 678, 692 (1978). However, a state is not liable for attorney's fees where the plaintiff sues the individual officer in his or her individual capacity. Graham, 473 U.S. at 167-68.

74. See supra note 28 and accompanying text. However, tort claims against federal employees may be brought against the United States under the Federal

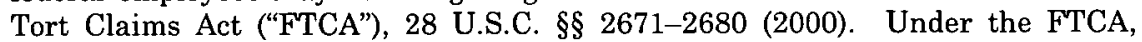
"[t]he United States shall be liable, respecting the provisions of this title relating to tort claims, in the same manner and to the same extent as a private individual under like circumstances, but shall not be liable for interest prior to judgment or for punitive damages." 28 U.S.C. $\S 2674$. The FTCA is the exclusive remedy in such cases, see United States v. Smith, 499 U.S. 160, 165-69 (1991), and government liability provided in the Act is limited by many exceptions, see Lawrence Rosenthal, A Theory of Governmental Damages Liability: Torts, Constitutional 
somewhat surprising given that the Court "recognized sound jurisprudential reasons for parallelism, as different standards for claims against state and federal actors 'would be incongruous and confusing." 75 Yet, the Court never expressly held that federal employees must have the same rights against their supervisors and their agencies as their state counterparts. ${ }^{76}$ Rather, the Court judicially created a damages remedy against federal officials who violate individuals' constitutional rights. It is to an explication of this Bivens doctrine that this Article now turns.

\section{B. Implying Actions for Money Damages for Constitutional Violations by Federal Agents}

Prior to 1971, a cause of action for money damages against federal agents who violated an individual's constitutional rights did not exist. ${ }^{77}$ In Bivens $v$. Six Unknown Named Agents of the Federal Bureau of Narcotics, ${ }^{78}$ the United States Supreme Court, for the first time, implied a cause of action for money damages against federal officers ${ }^{79}$ who violated the constitutional rights of individuals. Bivens involved the arrest and search of a man by the Federal Bureau of Narcotics. ${ }^{80}$ The man sued the individual federal officers involved in the incident, alleging that the arrest and search were carried out in violation of the Fourth Amendment's command against unreasonable search and seizure, ${ }^{81}$ and that the unlawful conduct

Torts, and Takings, 9 U. PA. J. CONST. L. 797, 804 (2007) (reviewing limitations).

75. Corr. Servs. Corp. v. Malesko, 534 U.S. 61, 82 (2001) (Stevens, J., dissenting) (quoting Butz v. Economou, 438 U.S. 478, 499 (1978)).

76. Id.

77. There have been unsuccessful Congressional attempts to legislate constitutional tort claims against the United States. See FDIC v. Meyer, 510 U.S. 471, 486 n.11 (1994) (citing H.R. 440, 99th Cong. (1st Sess. 1985); H.R. 595, 98th Cong. (1st Sess. 1983); S. 1775, 97th Cong. (1st Sess. 1981); H.R. 2659, 96th Cong. (1st Sess. 1979)).

78. 403 U.S. 388 (1971).

79. However, "[s]overeign immunity bars an action seeking to recover damages from the federal government itself for a constitutional tort." Rosenthal, supra note 74, at 815 (citing Meyer, 510 U.S. at 477 ).

80. Bivens, 403 U.S. at 389 . The Fed. Bureau of Narcotics was a predecessor agency of the Drug Enforcement Agency.

81. U.S. CONST. amend. IV ("The right of the people to be secure in their persons, houses, papers, and effects, against unreasonable searches and seizures, shall not be violated...."). 
caused him humiliation, embarrassment, and mental suffering. ${ }^{82}$

The Court started from the premise that, "it is . . . well settled that where legal rights have been invaded, and a federal statute provides for a general right to sue for such invasion, federal courts may use any available remedy to make good the wrong done." 83 It then held the plaintiff should also have a claim for money damages against the federal agents who violated his Fourth Amendment rights. ${ }^{84}$ In this manner, the Court sought to subject federal officials to the same type of constraints state officials are under when dealing with the fundamental rights of United States citizens, ${ }^{85}$ and to deter individual federal officers from acting unconstitutionally. ${ }^{86}$

Nevertheless, the Court limited this newly-minted Bivens right for future claims by a two-step analysis. Under the first step, "there is the question whether any alternative, existing process for protecting the interest amounts to a convincing reason for the Judicial Branch to refrain from providing a new and freestanding remedy in damages." 87 In other words, where Congress already provided an adequate remedial scheme for constitutional violations, it is unnecessary for the Court to craft a judge-made remedy. ${ }^{88}$ But even if no such alternative exists, a court must apply the second step of the analysis and under-

82. Bivens, 403 U.S. at 389-90.

83. Id. at 396 (quoting Bell v. Hood, 327 U.S. 678,684 (1946)).

84. Id. at 397.

85. Wilkie v. Robbins, 127 S. Ct. 2588, 2618 (2007) (Ginsburg, J., concurring in part and dissenting in part) ("Thirty-six years ago, the Court created the Bivens remedy. In doing so, it assured that federal officials would be subject to the same constraints as state officials in dealing with the fundamental rights of the people who dwell in this land."); see also id. ("The Bivens analog to $\S 1983$. . . is hardly an obscure part of the Court's jurisprudence.").

86. Corr. Servs. Corp. v. Malesko, 534 U.S. 61, 70 (2001). But see Bivens, 403 U.S. at 407-08 (Harlan, J., concurring) ("I agree with the Court that the appropriateness of according Bivens compensatory relief does not turn simply on the deterrent effect liability will have on federal official conduct.").

87. Wilkie, 127 S. Ct. at 2598 (citing Bush v. Lucas, 462 U.S. 367, 378 (1983)). Somewhat confusingly, this was the second step of the analysis set out in Carlson v. Green, 446 U.S. 14, 18-19 (1980), and the second step, involving "special factors counseling hesitation," was the first. Id. at 18. The majority opinion by Justice Souter in Wilkie gives no indication why the order of the analysis was reversed.

88. Bivens, 403 U.S. at 397 ("For we have here no explicit congressional declaration that persons injured by a federal officer's violation of the Fourth Amendment may not recover money damages from the agents, but must instead be remitted to another remedy, equally effective in the view of Congress."); see also id. at 410 (Harlan., J., concurring) ("For people in Bivens' shoes, it is damages or nothing."). 
take a "remedial determination that is appropriate for a common-law tribunal, paying particular heed . . . to any special factors counseling hesitation before authorizing a new kind of federal litigation." 89

Although Justice Brennan's opinion in Bivens is fairly straightforward, Justice Harlan's concurrence adds some important insights into the analysis. More specifically, Justice Harlan addresses "whether the power to authorize damages as a judicial remedy for the vindication of a federal constitutional right is placed by the Constitution itself exclusively in Congress' hands." 90 In other words, Harlan did not believe the existence of a damage remedy for constitutional violations should depend on Congressional legislative grace. Instead, he concluded:

[I]f a general grant of jurisdiction to the federal courts by Congress is thought adequate to empower a federal court to grant equitable relief for all areas of subject-matter jurisdiction enumerated therein, then it seems to me that the same statute is sufficient to empower a federal court to grant a traditional remedy at law. ${ }^{91}$

On another significant point, Justice Harlan responded to a suggestion Chief Justice Burger made in his dissent that constitutional violations by federal officers should be decided by quasi-judicial or administrative agencies created by Congress. ${ }^{92}$ Disagreeing with Burger's suggestion, Harlan wrote, "the judiciary has a particular responsibility to assure the vindication of constitutional interests such as those embraced by the Fourth Amendment."93 Harlan thought this especially applicable where "the Bill of Rights is particularly intended to vindicate the interests of the individual in the face of the popular will as expressed in legislative majorities."94 Nonetheless, he also

89. Wilkie, $127 \mathrm{~S}$. Ct. at 2598 (quoting Bush, 462 U.S. at 378). This "special factors counseling hesitation" language derives from Bivens, where the Court noted that a damage action was appropriate because the case involved "no special factors counseling hesitation in the absence of affirmative action by Congress." Bivens, 403 U.S. at 396.

90. Bivens, 403 U.S. at 401-02 (Harlan, J., concurring).

91. Id. at 405 (citation omitted). See also Bush v. Lucas, 462 U.S. 367, 378 (1983) ("The federal courts' statutory jurisdiction to decide federal questions confers adequate power to award damages to the victim of a constitutional violation.").

92. Id. at 422 (Burger, C.J., dissenting).

93. Id. at 407 (Harlan, J., concurring).

94. Id. See also JOHN HART Ely, DEMOCRACY AND DISTRUST 73-104 (1980). 
noted that the Court should think about policy considerations for and against adopting such an implied constitutional right, much in the way that the legislature does. ${ }^{95}$ Weighing the relevant policy considerations in Bivens, Justice Harlan concluded that there was not any substantial governmental policy that would be violated by recognizing a non-statutory damage remedy against federal officials allegedly responsible for a Fourth Amendment violation. ${ }^{96}$

After Bivens, the Court extended its reasoning to two additional contexts: employment discrimination suits against Congressional members for violations of the equal protection component of the Fifth Amendment's Due Process Clause, ${ }^{97}$ and cruel and unusual punishment actions by prisoners against federal prison officials under the Eighth Amendment. ${ }^{98}$ However, although Bivens has not been overruled, ${ }^{99}$ it has not been applied to any new types of cases since 1980.100 In 2007, the Court stated:

[A]ny freestanding damages remedy for a claimed constitutional violation has to represent a judgment about the best way to implement a constitutional guarantee; it is not an automatic entitlement no matter what other means there may be to vindicate a protected interest, and in most instances we have found a Bivens remedy unjustified. ${ }^{101}$

Even more to the point, in 2001, the Malesko Court held that a Bivens remedy would be limited to instances where there was either no other cause of action against individual officers alleged to have acted unconstitutionally or where a plaintiff lacked any alternative remedy for harms caused by an individual officer's unconstitutional conduct. ${ }^{102}$ Based on this restric-

95. Bivens, 403 U.S. at 407 (Harlan, J., concurring).

96. Id. at $408-10$.

97. See Davis v. Passman, 442 U.S. 228 (1979).

98. See Carlson v. Green, 446 U.S. 14 (1980).

99. At least two current Justices, Scalia and Thomas, would like to see Bivens and its progeny limited "to the precise circumstances that they involved." See Wilkie v. Robbins, 127 S. Ct. 2588, 2608 (2007) (Thomas, J., concurring) (quoting Corr. Servs. Corp. v. Malesko, 534 U.S. 61, 75 (2001) (Scalia, J., concurring)).

100. Malesko, 534 U.S. at 68 ("Since Carlson we have consistently refused to extend Bivens liability to any new context or new category of defendants."). See also Ryan D. Newman, Note, From Bivens to Malesko and Beyond: Implied Constitutional Remedies and the Separation of Powers, 85 TEX. L. REV. 471, 474 (2006) ("Although Bivens remains good law, in practice it seems a dead letter.").

101. Wilkie, 127 S. Ct. at 2597.

102. Malesko, 534 U.S. at 70. 
tive approach toward such claims, the Court refused to find Bivens remedies for claims involving: harm to military personnel through service activity, ${ }^{103}$ wrongful denials of Social Security benefits, ${ }^{104}$ and retaliation against the exercise of ownership rights under the Fifth Amendment's Takings Clause. ${ }^{105}$

The refusal of the current conservative Court to apply Bivens to other scenarios led Justice Ginsburg to suggest to Congress "to codify and further define the Bivens remedy" if it wanted federal officials to be subject to the same civil rights liability as state and local officials. ${ }^{106}$ The next section examines whether that might indeed be the most appropriate course after reviewing the current state of federal employees' First Amendment rights under Bivens.

\section{Application of Bivens to Federal Employment: Bush v. Lucas}

Given the focus of this Article on federal employees' First Amendment rights, Bush v. Lucas is the Court's most significant holding with regard to the scope of the Bivens remedy. ${ }^{107}$ $B u s h$ involved the demotion of a federal employee for allegedly making protected First Amendment statements critical of his federal agency. ${ }^{108}$ Although he appealed the adverse personnel decision to the Civil Service Commission and was reinstated with retroactive seniority and full back pay, ${ }^{109}$ under the administrative scheme he was not able to receive compensatory damages for emotional distress, punitive damages, or attorneys' fees against the individual federal official. ${ }^{110}$ There was,

103. See United States v. Stanley, 483 U.S. 669 (1987); see also Chappell v. Wallace, 462 U.S. 296 (1983).

104. See Schweiker v. Chilicky, 487 U.S. 412 (1988). Based on the language of the Bivens decision itself, and in order to further the deterrent functions of such individual damage actions, the Court has also held that Bivens actions may only be brought against individuals, not against federal agencies, or against private prisons acting on behalf of the State. See, e.g., Malesko, 534 U.S. at 61; FDIC v. Meyer, 510 U.S. 471 (1994).

105. Wilkie, $127 \mathrm{~S}$. Ct. at 2604-05.

106. Id. at 2618 (Ginsburg, J., concurring in part and dissenting in part).

107. 462 U.S. 367 (1983).

108. Id. at 369-71.

109. His first appeal was denied by the Federal Employee Appeals Authority, the predecessor to the MSPB, but was later upheld by Civil Service Commission's Appeal Review Board which applied the balancing of interests test under Pickering. Id. at 370-71. The Board awarded Bush reinstatement and $\$ 30,000$ in back pay. Id. at 386 n. 29 .

110. Id. at 371-72 \& nn.8-9. 
therefore, some issue over whether the administrative remedy adequately deterred unconstitutional conduct against the federal employee by his federal supervisor. ${ }^{111}$

Although the Court assumed that the administrative remedies did not provide complete relief for the plaintiff as effective as the Bivens damages remedy, ${ }^{112}$ the Court nevertheless unanimously ${ }^{113}$ concluded that a Bivens remedy did not exist under the First Amendment "aris[ing] out of an employment relationship that is governed by comprehensive procedural and substantive provisions giving meaningful remedies against the United States."114 More specifically, under the first step of the Bivens analysis, the Court found an effective, alternative remedy under the Civil Service Commission regulations. ${ }^{115}$ The Court defined its mission as making a "policy judgment . . . informed by a thorough understanding of the existing regulatory structure and the respective costs and benefits that would result from the addition of another remedy for violations of employees' First Amendment rights."116 Under this test, the Court found these civil service regulations to be "an elaborate remedial system that has been constructed step by step, with careful attention to conflicting policy considerations," 117 and it was unnecessary to "interfere with Congress' carefully calibrated system."l18

Even Justice Brennan, the author of the original Bivens decision, agreed with the outcome in Bush, writing in a later case that, "I agree that in appropriate circumstances we should defer to a congressional decision to substitute alternative relief

111. Id. at 372 n.8.

112. Id. at 388 ("[E]xisting remedies do not provide complete relief for the plaintiff.").

113. Justices Marshall and Blackmun concurred to register their belief that a similar case might come out differently if there were not a comprehensive scheme to provide full compensation for a constitutional violation that was substantially as effective as a damage action under the constitution. Id. at 390 (Marshall, J., concurring).

114. Id. at 368 (majority opinion).

115. Bush v. Lucas, 462 U.S. 367,388 (1983).

116. Id.

117. Id. This elaborate scheme was established by a series of federal civil service laws including: the Pendleton Act of 1883, 22 Stat. 403; the Lloyd-LaFollette Act of 1912, 37 Stat. 539; the Veterans Preference Act of 1944, 58 Stat. 387; the Backpay Act of 1966, 80 Stat. 94; and the Civil Service Reform Act of 1978, 92 Stat. 1111.

118. Wilkie v. Robbins, 127 S. Ct. 2588, 2612 (2007) (Ginsburg, J., concurring in part and dissenting in part). 
for a judicially created remedy."119 Brennan believed a substitute alternative remedy under the CSRA of 1978 was an appropriate circumstance because Congress developed the scheme over nearly a hundred years and "constitutional challenges . . . are fully cognizable' and prevailing employees are entitled not only to full backpay, but to retroactive promotions, seniority, pay raises, and accumulated leave." 120

Furthermore, the Court found special factors counseling hesitation under the second part of the Bivens analysis. In particular, the Bush Court 'recognized Congress' institutional competence in crafting appropriate relief for aggrieved federal employees as a 'special factor counseling hesitation in the creation of a new remedy."'121 In this regard, the Court observed that Congress could more expertly evaluate the effect of a new litigation right for federal employees than could the Court. ${ }^{122}$ It was not for the Court to decide whether it would be good pol. icy to permit a federal employee to recover damages against government officials in circumstances where Congress had already carried out the necessary balancing of employee rights and government efficiency interests. ${ }^{123}$ Indeed, recognizing a cause of action for constitutional violations in the federal employment relations "could upset Congress' careful structuring of federal employment relations." 124

Consequently, since 1983, federal employees have had to vindicate their First Amendment rights under an administrative scheme that provides less than complete relief. ${ }^{125}$ This is not to say that these employees should not have their First Amendment claims analyzed under the Pickering framework for public employee free speech claims. ${ }^{126}$ They do. The difference is that the framework will initially be applied by an AJ

119. Schweiker v. Chilicky, 487 U.S. 412, 431 (1988) (Brennan, J., dissenting).

120. Id. at 436 (quoting Bush v. Lucas, 462 U.S. $367,386,388$ (1983)).

121. Corr. Servs. Corp. v. Malesko, 534 U.S. 61, 68 (2001) (citing Bush, 462 U.S. at 380).

122. Bush, 462 U.S. at 389.

123. Id.

124. Schweiker, 487 U.S. at 441 (Brennan, J., dissenting).

125. Estlund, supra note 43, at 1484 ("[T] ime important point [of Bush] is the Court's conclusion that the administrative procedures and remedies of the civil service laws afford sufficient protection even for speech that is clearly protected by the First Amendment.") (emphasis added).

126. Indeed, the federal employee in Bush was successful after the Civil Service Commission Appeals Review Board applied the Pickering balance and found in the employee's favor. Bush, 462 U.S. at 370-71. 
appointed by the MSPB. ${ }^{127}$ Also, even if liability is found, an adjudicator will limit the damages to equitable relief and back pay. The federal employee will not be eligible for compensatory or punitive damages, and the tribunal will award attorney's fees on a more discretionary basis. ${ }^{128}$ Moreover, the current framework diminishes the deterrence function of the Bivens remedy because no individual liability exists against the federal officials responsible for the First Amendment deprivation. All this seems to suggest that the current remedies available to federal employees hardly act as a substitute remedy for a Bivens-type claim in the First Amendment federal employment relations context.

Nevertheless, the Court's focus in Bivens, and subsequently in Bush v. Lucas, concerns whether the administrative remedy provides meaningful redress to those federal employees bringing First Amendment claims. ${ }^{129}$ It is therefore necessary to examine in some detail the status of First Amendment retaliation claims under the CSRA of 1978. 130 To the extent that federal employees are not receiving similar treatment for their claims from the MSPB or the Federal Circuit, this alternative scheme is not providing a meaningful remedy. Justice Marshall is correct that a case like Bush v. Lucas should be decided differently in an environment in which Congress' comprehensive scheme is not providing "full compensation to civil service employees who are discharged or disciplined in violation of their First Amendment rights, and that [does not] afford[ ] a remedy that is substantially as effective as a damage action."131

127. For more detail about the MSPB and the role it plays under the Civil Service Act of 1978, see generally Part III.A.

128. 5 U.S.C. $\$ \S 7701(\mathrm{~g}), 1221(\mathrm{~g}), 1214(\mathrm{~g})$ (2000); 5 C.F.R. $\S \S 1201.201-$ 1201.204 (2008).

129. Bush, 462 U.S. at 386 ("[T] he Government's comprehensive scheme is costly to administer, but it provides meaningful remedies for employees who may have been unfairly disciplined for making critical comments about their agencies.") (emphasis added).

130. Professor Estlund has denominated this question as crucial to whether it makes sense to re-cast public employee First Amendment speech claims into liberty interests due some form of procedural process under the due process clause. See Estlund, supra note 43, at 1495 ("How good will administrative decisionmakers be at weighing free speech concerns against managers' claims of institutional imperative?").

131. Bush, 462 U.S. at 390 (Marshall, J., concurring). See also Schweiker v. Chilicky, 487 U.S. 412, 423 (1988) ("When the design of a Government program suggests that Congress has provided what it considers adequate remedial mechanisms for constitutional violations that may occur in the course of its administration, we have not created additional Bivens remedies."). 
Also, to the extent that the MSPB process is not working the way that it should, it undermines the argument concerning "special factors counseling hesitation" under which courts should defer to the institutional competence of Congress to decide these matters of federal employment law.

\section{Federal Employee First AMENDMENT Claims AND THE MSPB}

The following section considers how effectively the MSPB and the Federal Circuit have handled federal employees' First Amendment Pickering claims and whether federal employees, nearly twenty-five years after Bush, are receiving any semblance of meaningful redress for their constitutional claims. The section commences with a brief history of civil service laws in the United States before considering in depth both the structure of the MSPB and the Federal Circuit. It concludes by examining how these adjudicative bodies have handled First Amendment speech claims of federal employees.

\section{A. The History of Civil Service Law and Current Civil Service Regulations}

As the Court indicated in Bush v. Lucas, the federal civil service system in the United States is a product of many incremental legislative steps over 100 years, starting with the enactment of the Pendleton Act in 1883. ${ }^{132}$ The Pendleton Act established the Civil Service Commission, which aimed to defeat the spoils system and select federal public employees based on merit by using a competitive examination. ${ }^{133}$ Under Section 13, the Pendleton Act provided that employees could not be required to make political contributions or be politically influenced at the risk of being terminated. ${ }^{134}$ Over the next century, civil service laws were amended to provide federal employees with various employment rights, including just cause protection from termination, and from other adverse employment actions, ${ }^{135}$ unless such termination would promote the efficiency of the civil service. ${ }^{136}$ Additional laws provided

132. 22 Stat. 403.

133. Bush, 462 U.S. at 381.

134. See 5 U.S.C. $\S 2302(b)(3)$ (2000).

135. Veterans Preference Act of 1944, 58 Stat. 387.

136. Lloyd-LaFollette Act of 1912,37 Stat. 539, 555, $\$ 6$ ("no person in the clas- 
back pay and other make-whole relief for unlawful adverse employment actions. ${ }^{137}$ Importantly, in the Lloyd-LaFollette Act of 1912, Congress decided that granting free speech rights to federal employees was not counter to the efficient operation of the civil service. ${ }^{138}$

However, having the Civil Service Commission both prosecute and adjudicate federal employee personnel claims proved unworkable. Consequently, Congress passed the CSRA of $1978,{ }^{139}$ establishing a new adjudicative body, the MSPB, to hear prohibited personnel action claims involving civil service members. ${ }^{140}$ Further, in 1982, Congress required that the Federal Circuit Court of Appeals hear all appeals from MSPB decisions. ${ }^{141}$

The CSRA of 1978 set up an elaborate and comprehensive procedural and substantive framework for dealing with federal civil servants' First Amendment claims. ${ }^{142}$ Under this framework, substantive provisions prohibit arbitrary actions by federal supervisors, and procedural provisions provide administrative remedies for addressing unlawful actions taken against the employee. ${ }^{143}$

Substantively, the CSRA of 1978 established specific "prohibited personnel practices," including unlawful discriminatory actions, politically coercive actions, and retaliatory actions for whistleblowing. ${ }^{144}$ Significantly, for purposes of this Article,

sified Civil Service of the United States shall be removed therefrom except for such cause as will promote the efficiency of said service and for reasons given in writing . . . ."). The purpose of this legislation, in part, was to protect the free speech rights of civil service employees. H.R. REP. No. 62-388, at 7 (1912).

137. Back Pay Act of 1966, 80 Stat. 94; Back Pay Act of 1948, 62 Stat. 354.

138. Bush, 462 U.S. at 384.

139. Pub. L. No. 95-454, 92 Stat. 1111 (codified as amended in scattered sections of 5 U.S.C.).

140. 5 U.S.C. $\$ 7701(2000)$. The CSA of 1978 also established two other independent agencies: the Office of Personnel Management and the Federal Labor Relations Authority.

141. Id. $\S 7703$; Federal Court Improvement Act of 1982, 28 U.S.C. $\S 1295$ (2000).

142. Bush, 462 U.S. at 385.

143. Id. The administrative scheme does not protect all civil servants. For instance, probationary employees are excluded, 5 U.S.C. $\S 7511$ (2000), as are those employees who have been appointed by the President, 5 C.F.R. $\S 752.401(\mathrm{~d})(1)$, (3) (2008), have jobs which have "confidential, policy-determining, policy-making, or policy-advocating character," or are determined by the President to be excluded from coverage for conditions of good administration. 5 U.S.C. $\S 2302(a)(2)(B)(i)$, (ii) (2000). The law also provides that those suspended for fourteen days or less have no right to appeal a federal agency's decision. Id. $\S 7503$.

144. 5 U.S.C. $§ 2302(b)(1),(3),(8)$, (9) (2000). Federal employees may also 
federal civil servants are able to bring First Amendment claims under this scheme for personnel decisions based on the employee's disapproving or controversial comments about the agency. ${ }^{145}$

Procedurally, for an agency to remove an employee from his or her position, the burden is on the agency to show that such a removal would promote the efficiency of the service. ${ }^{146}$ Before this can happen, however, the agency must give the employee thirty days notice of a proposed adverse employment action, and the notice must contain reasons for the action. ${ }^{147}$ The employee, who may be represented by an attorney or another representative, is then given seven days to respond to the proposed action, and before taking final action, the agency must supply reasons for its decision. ${ }^{148}$

The employee may appeal the adverse decision under an applicable internal grievance procedure or to an AJ designated by the MSPB, but not both. 149 The AJ holds "a trial-type hearing at which the employee c[an] present witnesses, crossexamine the agency's witnesses, and secure the attendance of agency officials." 150 The AJ is required to issue a written decision. ${ }^{151}$ Successful employees are entitled to "make-whole" relief including reinstatement with back pay, but are not entitled

bring claims under the Whistleblower Protection Act of 1989 (WPA), Pub. L. No. 101-12, 103 Stat. 16 (codified as amended in scattered sections of 5 U.S.C.). Congress passed the WPA in light of federal government studies in 1980 and 1983 showing that, "[a] large percentage of Federal employees were reluctant to report instances of illegal or wasteful activities they had observed. Further, among those who did report such activities, a significant percentage felt they experienced some form of reprisal as a result." Cynthia L. Estlund, Free Speech and Due Process in the Workplace, 71 IND. L. J. 101, 119 n.71 (1995) (citing U.S. MERIT SYSTEMS PROTECTION BOARD, WHISTLEBLOWING IN THE FEDERAL GOVERNMENT: AN UPDATE (1993)). It does not appear, however, that the WPA has resolved the problem it was enacted to address. See supra note 14.

145. Bush, 462 U.S. at 386 ("Constitutional challenges to agency action, such as the First Amendment claims raised by petitioner, are fully cognizable within this [administrative] system.").

146. 5 U.S.C. $\S 7513(\mathrm{a})(2006)$; 5 U.S.C. $\$ 7701$ (c)(1) (2006) (placing the burden on the agency for the merits of the case); 5 C.F.R. $\S 1201.56(a)(1)(i i)(2008)$.

147. 5 U.S.C. $\S 7513(\mathrm{~b})(1)$.

148. 5 U.S.C. $\S 7513(\mathrm{~b})(2)-(4)$.

149. 5 C.F.R. $\S 752.405(\mathrm{~b})$ (2008). There may be reasons to believe that employees fare better under a negotiated grievance process under this scheme. See infra note 261. However, the focus of this paper is on the efficacy of the AJ/MSPB system.

150. Bush, 462 U.S. at 387 (citing 5 C.F.R. $§ 772.307$ (c) (2008)). See generally 5 U.S.C. $\S 7701$ (2006); 5 C.F.R. $§ 1200$ (2008).

151. 5 U.S.C. $\S 7701(\mathrm{~b})(1)$. 
to compensatory or punitive damages. ${ }^{152}$ Attorney's fees can be awarded by the MSPB on a discretionary basis. ${ }^{153}$

If the employee does not win at the AJ/initial appeal level, he or she may file a petition for review with the MSPB. Regardless of whether the MSPB accepts review, the employee may appeal to the Federal Circuit. ${ }^{154}$ However, the employee will not be entitled to a full review of his or her claims before the Federal Circuit, as would a plaintiff asserting a Bivens claim in front of a federal trial court. Instead, the Federal Circuit reviews the MSPB's or AJ's decision under a highly deferential arbitrary and capricious standard. 155

Overall, this federal civil service administrative scheme has advantages and disadvantages compared to a direct Bivens damage action under the Constitution. Disadvantages include a lack of the following: access to an impartial Article III court (and the politically appointed members of the MSPB in the court's stead), jury trials, ${ }^{156}$ the ability to obtain compensatory and punitive damages, full appeal rights in front of the Federal Circuit, ${ }^{157}$ and the ability to bring claims for money damages against individuals responsible for the violation of constitutional rights (and therefore, a loss of significant deterrence interests). Attorney's fees are also more discretionary under the administrative model. ${ }^{158}$ On the one hand, the administrative process is advantageous to employees, as it places the burden of proof on the agency, ${ }^{159}$ gives employees due process rights which might provide more effective protection for speech than First Amendment rights alone, ${ }^{160}$ negates the need to argue

152. Id.

153. 5 U.S.C. $\S 7701(\mathrm{~g})(1)$ (adopting "interest of justice" standard for most adverse employment action cases).

154. 5 U.S.C. $\$ 7703(\mathrm{a})(1)$, (d) (2006).

155. "The decision of the MSPB must be affirmed unless we find it to be arbitrary, capricious, an abuse of discretion, or otherwise not in accordance with law; obtained without procedures required by law, rule, or regulation having been followed; or unsupported by substantial evidence." Holland v. Dep't of Air Force, 31 F.3d 1118, 1120 (Fed. Cir. 1994) (citing 5 U.S.C. $§ 7703(c)$ ).

156. See Carlson v. Green, 446 U.S. 14, 22-23 (1980).

157. See Chandler v. Roudebush, 425 U.S. 840, 851-53 (1976).

158. Allen v. U.S. Postal Service, 2 M.S.P.R. 420, 429 (1980) ("The circumstances justifying the award of attorney's fees is left to the discretion of the Board to develop in light of its experience. The award of attorney's fees should not become, however, the ordinary practice in cases which the employee wins.") (emphasis in original).

159. See supra note 146 and accompanying text.

160. This is the argument advanced by Professor Estlund. See Estlund, supra note 144, at 124 (" $[\mathrm{T}]$ hose employees who enjoy independent due process rightswho cannot be fired without a good reason or without notice and a hearing- 
against qualified immunity in order to obtain damages, ${ }^{161}$ and provides a process that is likely to be more accessible, quicker, and less costly. ${ }^{162}$

To determine whether the advantages of the MSPB process for deciding First Amendment claims of federal employees outweigh the disadvantages, it is necessary to consider whether the established alternative remedy to a direct constitutional claim is providing "meaningful redress" to impacted federal employees. In other words, it is necessary to explore how the MSPB and the Federal Circuit have been handling federal employees' First Amendment retaliation claims to determine whether a Bivens remedy is necessary in this sub-class of cases. ${ }^{163}$ The next two subsections focus on this topic.

\section{B. The MSPB Experience Handling First Amendment Pickering Claims}

Protection for civil service federal employees who speak out on controversial issues of public concern has never been good. Indeed, the state of affairs was so bleak that Congress passed the Whistleblower Protection Act of 1989 ("WPA") 164 as an attempt to give federal employees more protection from retaliation for exercise of First Amendment rights in the work-

should be expected to enjoy much greater freedom of expression as well."). I wonder, however, whether in a potentially politicized environment like the MSPB, whether such procedural rights will really help. Although civil servants have the advantage of putting the burden on agencies to "reasonably investigate and evaluate whatever facts it is relying upon before imposing serious discipline," id. at 128-29, the danger is that such investigations will be form over substance where political considerations are involved and illustrates another reason why the independent Article III court is necessary. On the other hand, if due process is defined as "the right to notice of the charges and to a hearing before an impartial decisionmaker at which the employer must show just cause for discipline or discharge and the employee may respond," id. at 129 , I do not believe that federal employees are entitled to an impartial decisionmaker pre-termination under Cleveland Bd. of Educ. v. Loudermill, 470 U.S. 532, 546 (1985). Moreover, the MSPB, as discussed below, seems far from an impartial post-termination administrative decisionmaker. See infra Part III.B.

161. See Butz v. Economou, 438 U.S. 478, 508-17 (1978) (applying Section 1983 qualified immunity standard for state officials to federal officials).

162. See Estlund, supra note 144, at 129 ("The administrative process for adjudicating just cause discharges is much cheaper and more prompt, and consequently more accessible to most employees, than civil litigation.").

163. "The question is obviously crucial: If administrative hearings ended up serving as a rubberstamp for managers' decisions, they would not serve the First Amendment values and interests at stake." Estlund, supra note 43, at 1491.

164. Pub. L. No. 101-12, 103 Stat. 16 (codified at 5 U.S.C. $\$ \$ 1211-1219,1221-$ $1222,3352(2006))$. 
place in matters of reporting waste, fraud, or abuse. ${ }^{165}$ But even after passage of the 1989 law, Professor Estlund was able to conclude, based on findings from a 1992 report, that "many employees who observe wrongdoing do not report it, that many of those who do so perceive employer retaliation, albeit of a comparatively mild variety, and that many of those who do not report wrongdoing attribute their unwillingness to speak out to the fear of retaliation."166 Indeed, in 2007 Congress seriously considered the first "enhancement" to the WPA in eighteen years. 167 Currently, however, fear of retaliation in the federal workplace for unwanted speech remains a substantial issue in the federal civil service. ${ }^{168}$ Since 1982 , these concerns have been raised by federal employees in front of the MSPB, either in whistleblowing suits or in First Amendment retaliation

165. Estlund, supra note 144, at 119 n.71.

166. Id. at 120 .

167. Government Accountability Project, House Approves Landmark Whistleblower Legislation (Mar. 14, 2007), http://www.whistleblower.org/ content/press_detail.cfm?press_id=831 ("The Government Accountability Project (GAP) hailed this evening's House of Representatives floor vote approving H.R. 985, the Whistleblower Protection Enhancement Act, legislation that overhauls federal whistleblower law. The vote was $229-0$ by Democrats, and 102-94 among Republicans."). The bill is currently pending in the Senate. The Bill would extend whistleblower protections to national security employees, employees of government contractors, and employees of science-based agencies. House Committee on Oversight and Government Reform, Whistleblower Protection Enhancement Act of 2007 (Feb. 13, 2007), http://oversight.house.gov/story.asp?ID=1172. It would also expand the "scope of disclosures protected under current law ... . [and] clarify[ ] that 'any' disclosure regarding waste, fraud, or abuse means 'without restriction as to time, place, form, motive, context, or prior disclosure' and includes formal or informal communication." Rep. Henry A. Waxman, Bill Summary of The Whistleblower Protection Enhancement Act of 2007, http://oversight.house. gov/documents/20070213145031-52587.pdf. Perhaps most importantly, it would provide an escape-hatch from MSPB/Federal Circuit procedures altogether if the MSPB does not act on a case within 180 days. Id. However, unlike the Equal Employment Opportunity Commission, the MSPB-designated AJ does hear cases fairly quickly and so this provision might not provide adequate relief from the current system. See Edward H. Passman \& Bryan J. Schwartz, In the Name of Security, Insecurity: The Trend to Diminish Federal Employees' Rights, 21 LAB. LAW. 57, 62 (2005) ("The MSPB regulations expedite the hearing process for adverse actions and other statutory appeals, strongly encouraging MSPB administrative judges (AJs) to issue initial decisions within 120 days.").

168. See Garcetti v. Ceballos, 547 U.S. 410, 441 (2006) (Souter, J., dissenting) ("Most significantly, federal employees have been held to be unprotected for statements made in connection with normal employment duties [under the WPA], the very speech the majority says will be covered . ..."). See also Estlund, supra note 144 , at 142 ("[T] gests a fairly high level of managerial hostility and employee 'silence' (failure to report perceived wrongdoing) even in the most legally protected environment."). 
suits. ${ }^{169}$ With this Article's focus on the First Amendment, the question remains: how effectively is the MSPB addressing the First Amendment concerns of federal employees? ${ }^{170}$

\section{The Structure and Characteristics of the MSPB}

The answer appears to be based largely on the structure and characteristics of the MSPB, which hears appeals of personnel actions brought by over two million covered federal employees. ${ }^{171}$ As part of the Executive Branch, the MSPB describes itself as "serv[ing] as an independent, bipartisan guardian of the merit systems under which Federal employees work." 172 Yet, there remains a question concerning independence because members of the MSPB are political appointees. ${ }^{173}$ With its full complement, the MSPB consists of three mem-

169. "In the context of an adverse action against a public employee, the [whistleblowing] rights under section 2302(b)(8)(A) (prohibition of reprisal) and the First Amendment's right to free speech have been considered coextensive rights." Fiorillo v. U.S. Dep't of Justice, Bureau of Prisons, 795 F.2d 1544, 1549 (Fed Cir. 1986) (citing Gerlach v. FTC, 9 M.S.P.R. 268 (1981)). This article focuses on the First Amendment, but the impact that the federal whistleblower statutes have on this area of the law cannot be ignored. The presence of such whistleblower laws has given federal employees alternative means to hold their government employers accountable, but has also proven something else: that such laws do not effectively fill the gap left by the lack of First Amendment protection, contrary to Justice Kennedy's assertions in Garcetti, 547 U.S. at 421-23.

170. See Estlund, supra note 43, at 1491 ("While the experience of employees with First Amendment claims under the federal civil service laws, where these claims were channeled by Bush v. Lucas, would be instructive, it would be difficult to evaluate that experience and to extrapolate to the much larger and more varied universe of state and local employment."). I do not attempt, however, to undertake the difficult extrapolation of the federal experience to state and local employment in this article.

171. There are approximately three million federal workers in the United States. See William F. West \& Robert F. Durant, Merit, Management, and Neutral Competence: Lessons from the U.S. Merit Systems Protection Board, FY 1988 . FY 1997, 60 PUB. ADMIN. REV. 111, 112 (2000). Two-thirds, or approximately two million employees, are covered by the Civil Service Reform Act of 1978 and the procedures of the MSPB. Id.

172. MSPB.GOV, Welcome from Neil A.G. McPhie, available at http:// www.mspb.gov/sites/mspb/default.aspx (last visited Aug. 3, 2008).

173. In this vein, Tom Devine, legal director for the Government Accountability Project ("GAP") in Washington D.C., contends: "These [Board Member positions] are stepping stones for bigger and better things. They know the way to get ahead in the administration is not to support whistle-blowers who embarrass presidents." Timothy W. Maier, Entrapping the whistle-blowers - efforts to stop gouernment corruption, INSIGHT ON THE NEWS, Feb. 2, 1998, available at http://findarticles.com/p/articles/mi_m1571/is_n4_v14/ai_20212840 (last visited Aug. 3, 2008). 
bers, ${ }^{174}$ no more than two members from any one political party. ${ }^{175}$ The members are approved by the Senate and serve overlapping seven-year terms. ${ }^{176}$

The MSPB received over 8500 appeals of civil service personnel decisions in 2006. ${ }^{177}$ Of these, about fifty percent in any given year involve adverse employment action claims, including terminations, suspensions, demotions, failures to promote, and other adverse employment actions. ${ }^{178}$ The standard in such cases is whether adverse employment actions are supported by such cause as will promote the efficiency of the public service. ${ }^{179}$ Most of these appeals are initially heard by AJs designated by the MSPB at five regional offices throughout the country. 180 Unsuccessful parties before the AJs (mostly employees) may file petitions for review ("PFRs") with the MSPB. ${ }^{181}$ In recent years, there have been between 1000 and 2000 PFRs, with the large majority (anywhere from eighty-four to ninety-four percent) resulting in the MSPB affirming the

174. West \& Durant, supra note 171. The President has the ability to desig. nate the chairperson. Id. The current members of the Board are Chairman Neil A.G. McPhie (Republican) and Vice Chairwoman Mary M. Rose (Republican), MSPB.gov, Board Members, http://www.mspb.gov/sites/mspb/pages/ About\%20MSPB.aspx (last visited Aug. 3, 2008). Chairman McPhie is an attorney, while Vice-Chair Rose is not. Id. Vice-Chair Rose has served in many political capacities and was employed by the conservative Heritage Foundation. See id.

175. West \& Durant, supra note 171. See also Carol Goldberg, Chambers Termination Upheld - Appeal Planned, PUBlic EMPLOYEES FOR ENVIRONMENTAL RESPONSIBILITY, Sept. 21, 2006, available at http://www.peer.org/news/ news_id.php?row_id $=753$ (observing that current Board has two Republicans and one Democrat) (last visited Aug. 3, 2008).

176. 5 U.S.C. $\S 1202(2006)$. The seven-year term would seem to help insulate the Members from political influence, but the analysis of MSPB First Amendment cases appears to undermine this theory. See infra Part III.B.2.

177. Merit Systems Protection Board, FY 2006 Performance and Accountability Report (PAR) 7 (Nov. 16, 2006), available at http://www.mspb.gov/ netsearch/viewdocs.aspx? docnumber $=277562 \&$ version $=277871 \&$ application $=$ ACROBAT (last visited Aug. 3, 2008). By contrast, in the period from 1988-97, it handled 6500 to 7500 appeals. West \& Durant, supra note 171, at 113.

178. West \& Durant, supra note 171 , at 113 . The other fifty percent primarily involve reductions-in-force and retiree benefit claims. Id.

179. VAUGHAN, supra note 11 , at $\S 12.01,12-2$. This has been the standard since 1912. Id.

180. West \& Durant, supra note 171 , at 113 . The MSPB has the power by statute to delegate cases to AJs. 5 U.S.C. $§ 1204$ (g) (2006) ("The Board may delegate the performance of any of its administrative functions under this title to any employee of the Board."). Thus, AJs are actually considered to be employees of the MSPB. Decisions from the administrative judges are discretionary and the MSPB does not consider these AJ decisions precedential. VAUGHN, supra note 11 , $\S 5.01$ at 5-2 \& n.6 (citing Horner v. Burns, 793 F.2d 196, 201 (Fed. Cir. 1986)).

181. West \& Durant, supra note 171 , at 113. 
AJ's decision. ${ }^{182}$ The large percentage of unchanged awards is based on the relatively high standard a PFR must meet in order to be reviewed by the MSPB. Petitions are granted "only when significant new evidence is presented to [the MSPB] that was not available for consideration earlier or when the administrative judge made an error interpreting a law or regulation."183 Nevertheless, even petitions denied review may still be appealed to the Federal Circuit. ${ }^{184}$

Very few of the PFRs that are accepted by the MSPB involve First Amendment claims by employees. ${ }^{185}$ A query of MSPB decisions involving First Amendment claims on the Westlaw FLB-MSPB database disclosed only seventy-seven decisions from 1979 to 2007, an average of less than three per year-this is a minuscule percentage of the more than 10,000 decisions the MSPB issued during this same period. ${ }^{186}$ Of these First Amendment decisions, only twenty-three involve any mention of the First Amendment balancing analyses under Connick and Pickering. ${ }^{187}$

182. Id. at 115 (Table 2, statistics from 1990-97). Of the remaining PFRs, about two percent are settled, three to four percent are reversed, seven to eight percent are remanded, and two percent result in mitigated remedies. Id.

183. Heaggans v. Dep't of Defense, 101 M.S.P.R. 159, 160 (2006) (citing 5 C.F.R. $§ 1201.115(2008)$ ).

184. 5 U.S.C. $\$ 7703(\mathrm{a})(1)$, (d) (2006).

185. Indeed, some First Amendment claims were decided against the employee by administrative judges, denied review by the MSPB, and then affirmed on the substance by the Federal Circuit-providing yet another route by which federal employee constitutional claims do not receive the constitutional protection they deserve. See, e.g., Henry v. Dep't of Navy, 902 F.2d 949, 950-51 (Fed. Cir. 1990).

186. The Westlaw query included the search terms: “first amendment' and Pickering or Mings or Sigman." Mings and Sigman are the primary Federal Circuit and MSPB precedent discussing Pickering rights. See Mings v. Dep't of Justice, 813 F.2d 384, 387 (Fed.Cir. 1987); Sigman v. Dep't of Air Force, 37 M.S.P.R. 352 (1988). A similar search on the MSPB.gov database disclosed only fifty-nine such decisions. MSPB.gov, Decisions, http://www.mspb.gov/sites/ mspb/pages/MSPB\%20Decisions.aspx (advanced search terms were " 'First Amendment' or 'first amendment' or '1st Amendment.' "). The reason for the discrepancy appears to be that fifteen cases from 1980-83 are inexplicably not reported in the MSPB.gov database and a few other cases are counted in Westlaw twice if they were remanded by the Federal Circuit.

187. One of the early cases, Farris v. U.S. Postal Serv., 14 M.S.P.R. 568 (1983), does sustain a First Amendment claim by a federal employee, but it applies a preConnick analysis that is inconsistent with the other cases decided since the 1983 Connick decision. Id. at 572-73. Other cases mention the First Amendment for procedural or jurisdictional reasons, see, e.g., Wright v. Dep't of Army, 100 M.S.P.R. 274 (2005), and others mention First Amendment claims without deciding them, see, e.g., Wilson v. Dep't of Justice, 66 M.S.P.R. 287 (1995). In the latter instance, this approach is followed because if the employee obtains redress under other provisions of the civil service law, the Board finds it unnecessary to examine 
Most significantly, however, is the fact that all twenty. three remaining decisions involve either a finding of no First Amendment violation ${ }^{188}$ or no decision on the First Amendment issue. ${ }^{189}$ Two of the most recent Pickering MSPB cases, discussed below, represent the pattern in almost all of the cases decided on the merits: a finding that the employee did not speak out on a matter of public concern under a narrow definition of public concern, followed by an alternative argument that even if public concern speech is involved, the employee's First Amendment rights are easily outweighed by the countervailing efficiency interests of the employer. ${ }^{190}$ In short, outside of Bush $v$. Lucas, which was decided by the MSPB's predecessor agency, there has not been a single published case decided by the MSPB on the merits, where an employee's First Amendment Pickering rights have been upheld.

\section{Two Representative Pickering MSPB Cases: Chambers and Smith}

Two recent MSPB cases, Chambers $v$. Department of the Interior ${ }^{191}$ and Smith v. Department of Transportation, ${ }^{192}$ illus-

the constitutional issue. See infra note 246 and accompanying text.

188. Smith v. Dep't of Transp., 106 M.S.P.R 59 (2007); Chambers v. Dep't of Interior, 103 M.S.P.R. 375 (2006); Heaggans v. Dep't of Defense, 101 M.S.P.R. 159 (2006) (PFR denied 2-1, but dissent filed by Chairman McPhie finding employee had suffered no violation of First Amendment rights); Johnson v. Dep't of Justice, 65 M.S.P.R. 46 (1994); Henry v. Dep't of Navy, 40 M.S.P.R. 482 (1989); Jackson v. Small Bus. Admin., 40 M.S.R.P. 137 (1989); Soc. Sec. Admin. v. Burris, 39 M.S.P.R. 51 (1988); Sigman v. Dep't of Air Force, 37 M.S.P.R. 352 (1988); Wenzel v. Dep't of Interior, 33 M.S.P.R. 344 (1987); Ledeaux v. Veterans Admin., 29 M.S.P.R. 440 (1985); Osokow v. Office of Pers. Mgmt., 25 M.S.P.R. 319 (1984); Barnes v. Dep't of Army, 22 M.S.P.R. 243 (1984); Brown v. F.A.A., 21 M.S.P.R. 572 (1984); Curry v. Dep't of Navy, 13 M.S.P.R. 327 (1982); Wittenberg v. U.S. Postal Serv., 12 M.S.P.R. 617 (1981); Prescott v. Dep't of Health \& Human Servs., 6 M.S.P.R. 252 (1981); Quarry v. Gen. Acct. Office, 3 M.S.P.R. 200 (1980).

189. Wilson v. Dep't of Justice, 66 M.S.P.R. 287, 297 (1995) ("Because the charge does not set forth actionable misconduct, we need not reach the appellant's claim that his speech was protected by the First Amendment."); Oliver v. Dep't of Health \& Human Servs., 34 M.S.P.R. 465 (1987) (decided as whistleblower case); Special Counsel v. Dep't of State, 9 M.S.P.R. 363 (1982) (decided under civil service provisions); Schofield v. Veterans Admin., 7 M.S.P.R. 94, 98 (1981) (passing on "serious constitutional question," and deciding case on statutory grounds).

190. The Chambers case, discussed in detail in Part III.B.2.a, is an exception because it was decided based on the newly-available ground of official duty speech available since Garcetti v. Ceballos, 547 U.S. 410 (2006). But there is still an argument in the alternative under the Pickering balance, and of course, the case comes out in favor of the agency.

191. 103 M.S.P.R. 375 (2006), rev'd in part, 515 F.3d 1362 (Fed. Cir. 2008). 
trate how the MSPB has historically dealt with these types of First Amendment claims.

\section{a. Chambers v. Department of Interior}

In Chambers $v$. Department of Interior, Teresa Chambers had been appointed the Chief of the United States Park Police in 2002.193 When Chambers became concerned about park police deployment post-9/11 and the department's lack of budgetary resources, she shared her dissatisfaction with a Washington Post reporter in comments published in December, 2003. ${ }^{194}$ Almost immediately, Chambers was placed on paid administrative leave and her superiors proposed to remove her from her position because she had discussed security and budgetary matters with third parties and did so without going through her chain of command.195 After her official termination, Chambers brought whistleblowing and First Amendment retaliation claims under the civil service regulations. ${ }^{196}$

The administrative law judge upheld her termination, finding that she had disclosed sensitive security and budgetary information, failed to carry out her supervisor's instructions, and failed to follow the chain of command. ${ }^{197}$ On the First Amendment issue, the AJ held that she did not speak as a citizen and therefore, under Garcetti, ${ }^{198}$ had no First Amendment protection. 199

The MSPB granted the PFR and affirmed the AJ's decision. ${ }^{200}$ Specifically on the First Amendment claim, the MSPB recognized that public employees have constitutional rights under Connick and Pickering, but then looked to the applicable Federal Circuit precedent as requiring that “ $[\mathrm{e}]$ mployees' free speech rights must be balanced . . . against the need of gov-

The decision on appeal is inconsequential to this analysis as it did not relate to the First Amendment claims in Chambers.

192. 106 M.S.P.R. 59 (2007). As of the writing of this article, no appeal has been filed.

193. Chambers, 103 M.S.P.R. at 378.

194. Id. at 380 . She made similar comments to a House subcommittee staffer. Id.

195. Id. She was officially terminated in July 2004 by the Deputy Secretary of the Interior. $I d$. at 381.

196. Id.

197. Id. at 380 .

198. 547 U.S. 410 (2006)

199. Chambers, 103 M.S.P.R. at 392.

200. Id. at 394 . 
ernment agencies to exercise wide latitude in managing their offices, without intrusive oversight by the judiciary in the name of the First Amendment."201

Nevertheless, the MSPB decided the case under Garcetti, finding that the employee's speech to the reporter was pursuant to her official duties and thus, not protected by the First Amendment. ${ }^{202}$ In support of this conclusion, the MSPB noted that Chambers had contested a gag order that would not allow her to speak to the press under any circumstance because it was her job to speak to the press about agency issues. ${ }^{203}$ The MSPB thus defined the scope of her job duties based on how the MSPB believed Chambers perceived her job duties. ${ }^{204}$

As I have argued elsewhere, Garcetti is a prime example of poor judicial reasoning and opinion writing that will hopefully go the way of Bowers v. Hardwick. ${ }^{205}$ Be that as it may, even applying Garcetti to the facts of this case, not all public employee speech is created equal, 206 and the MSPB seems to think that whenever a federal employee talks to a newspaper, that employee must be talking in his or her official capacity. Yet, the MSPB fails to do the functional analysis of job responsibilities that Garcetti requires. ${ }^{207}$ Moreover, the MSPB came to its conclusion even though the Garcetti Court specifically mentioned that a public employee speaking to a reporter on his or her own time likely would not be speaking pursuant to official

201. Id. at 391 (citing Mings v. Dep't of Justice, 813 F.2d 384, 387 (Fed.Cir. 1987)). This version of the Pickering balance test is one that has been transformed with the government's finger heavily on the side of the government. See infra notes 227-31 and accompanying text.

202. Id. at 392. Member Sapin dissented on the whistleblower claims, but agreed with the majority's First Amendment conclusion. Id. at 421 (Sapin, Member, dissenting). Alternatively, just because a person talks with the press as part of her job responsibilities does not necessarily mean that all of her conservations with the press are job-related.

203. Id.

204. Id.

205. 478 U.S. 186 (1986), overruled by Lawrence v. Texas, 539 U.S. 558 (2003). For a discussion of the multiple problems with Garcetti, see Paul M. Secunda, More Than Employees: Citizens Working in Government Need Better Constitutional Protection from Retaliation, LEGAL TIMES, May 21, 2007.

206. Garcetti, 547 U.S. at $423-25$.

207. Id. at 424-25 ("The proper inquiry is a practical one. Formal job descriptions often bear little resemblance to the duties an employee actually is expected to perform, and the listing of a given task in an employee's written job description is neither necessary nor sufficient to demonstrate that conducting the task is within the scope of the employee's professional duties for First Amendment purposes."). 
duties. ${ }^{208}$ It certainly was not Chambers' duty to criticize her employer for its security and budgetary decisions. Indeed, the criticism is most comparable to the Pickering case itself where the school teacher wrote a letter to a newspaper criticizing the school district's budgetary decisions. ${ }^{209}$ In short, the majority decision by the MSPB and its legal reasoning is highly questionable and suggests a tendency on the part of some board members to favor the interests of the federal employer over those of the federal employee. ${ }^{210}$

Because Chambers was filed prior to Garcetti, the MSPB also concluded, in the alternative, that Chambers would have lost her case under pre-Garcetti law. ${ }^{211}$ The MSPB found that although Chambers spoke out on a matter of public concern, she lost on the Pickering balance because police officers, and especially chiefs of police, have less First Amendment protection than other public employees. 212

This categorical approach to Pickering balancing, however, is at odds with the required individualized balancing based on the specific facts of the case. ${ }^{213}$ Because of Chambers' serious public safety concerns, the harm caused to working relation-

208. Id. at 423 ("Employees who make public statements outside the course of performing their official duties retain some possibility of First Amendment protection because that is the kind of activity engaged in by citizens who do not work for the government. The same goes for writing a letter to a local newspaper.").

209. Pickering v. Bd. of Education, 391 U.S. 563, 566-67 (1968).

210. This hunch is also based on other background evidence. For instance, Vice-Chairman Rose, a Republican appointee, held previous positions as Deputy Associate Director of the Office of Presidential Personnel at the White House under the current President Bush and as a "Visiting Fellow with The Heritage Foundation where she recruited, interviewed and recommended Presidential Appointments to the George W. Bush transition team." MSPB.gov, Board Members, available at http://www.mspb.gov/sites/mspb/pages/About\%20MSPB.aspx (last visited Aug. 3, 2008). The Heritage Foundation is a conservative, generally proemployer institution in Washington D.C. See The Heritage Foundation, About Us, available at http://www.heritage.org/about ("Founded in 1973, The Heritage Foundation is a research and educational institute $-a$ think tank-whose mission is to formulate and promote conservative public policies based on the principles of free enterprise, limited government, individual freedom, traditional American values, and a strong national defense.") (last visited Aug. 3, 2008). Less cynically, this faulty legal analysis may be the result of what happens when members of the Board are not attorneys, like Vice-Chairwoman Rose.

211. Chambers v. Dep't of the Interior, 103 M.S.P.R. 375, 392-93 (2006). Member Sapin dissented on this alternative ground, but did not expound on her reasons for doing so. Id. at 421 (Sapin, Member, dissenting).

212. Id. at 393 .

213. Brown v. Dep't of Transp., FAA, 735 F.2d 543, 548 (Fed. Cir. 1984) ("It is the duty of the court to perform a 'particularized balancing' between the competing interests."). 
ships by her criticisms outweighed the benefit to the public interest in safety, especially when one takes into account the unique knowledge Chambers had when it came to the affairs of the Park Police. In defense of its position, the MSPB majority stated: "[C]onsistent with the decisions cited above, the agency had an overriding interest in not having the Chief of the Park Police publicly question decisions made by officials who outranked her concerning the functions and budget of the Park Police."214 Yet, if that were always the case, there would be fewer First Amendment rights for public employees who, as citizens, believe they are uniquely situated to bring concerns about the government to the attention other citizens. Indeed, the MSPB seems to recognize this when it cites a Seventh Circuit case for the proposition that " $[t]$ he public's interest in learning about 'corruption' or 'wrongdoing' by government officials will usually foreclose discipline against a public employee who reveals such activities, even when the speaker is a law enforcement officer with limited First Amendment rights."215 But somehow, the MSPB's decision indicates that it believes danger to public safety is less important than other types of "wrongdoing" or "corruption," and thus the Seventh Circuit precedent should not apply.216 In short, the MSPB's analysis is lacking, superficial, and inconsistent with the type of competent legal analysis required in these types of cases. ${ }^{217}$

\section{b. Smith v. Department of Transportation}

There is not much improvement in the MSPB's handling of Smith v. Department of Transportation. ${ }^{218}$ Smith involves the thirty-day suspension of a Department of Transportation employee for using, in an allegedly unauthorized manner, government documents to support his equal employment opportunity claim revolving around an allegedly racially

214. Chambers, 103 M.S.P.R. at 393.

215. Id. at 394 (citing McGreal v. Ostrov, 368 F.3d 657 (7th Cir. 2004)).

216. See id. at 393-94.

217. Adjudicatory agencies like the MSPB need to have credibility with parties on both sides of the dispute. See Paul M. Secunda, Politics Not As Usual: Inherently Destructive Conduct, Institutional Collegiality, and the National Labor Relations Board, 32 FLA. ST. U. L. REV. 51, 54 n.11 (2004) (maintaining that in the context of National Labor Relations Board, "[b]oard decisions driven by political considerations negate the Board's claim of superiority in deciding labor disputes based on industrial experience and expertise and compromise its stature as a neutral independent agency").

218. 106 M.S.P.R. 59 (2007). 
discriminatory failure to promote. ${ }^{219}$ Smith claimed, among other things, that the thirty-day suspension violated his First Amendment right to challenge the allegedly discriminatory promotion decision. 220 Because the AJ sustained Smith's initial appeal on other grounds, there was no need to discuss his First Amendment claim. ${ }^{221}$ However, the First Amendment claim became relevant again when the MSPB overturned some of the AJ's conclusions on the civil service provisions.

Although recognizing the constitutional speech rights of all public employees under the Pickering framework, the MSPB relied on an interpretation by the Federal Circuit that placed a heavy thumb on the scale on the side of the government's interests. 222 Under the Mings test, " 'employees' [free speech rights] must be balanced . . . against the need of government agencies for 'wide latitude in managing their offices, without intrusive oversight by the judiciary in the name of the First Amendment." "223 But the Federal Circuit in Mings made a glaring legal mistake by suggesting that this "wide latitude" language concerns the balancing of employee and employer interests under Pickering. Instead, the "wide latitude" language concerns the threshold question of whether or not the employee is due some First Amendment protection because he or she is speaking on a matter of public concern. The complete quote from Connick states, "When employee expression cannot be fairly considered as relating to any matter of political, social, or other concern to the community, government officials should enjoy wide latitude in managing their offices, without intrusive oversight by the judiciary in the name of the First Amendment."224

So only when public-employee speech is not on a matter of public concern at all does the employer have wide latitude to manage its offices, not when the expression is important to public debate. When public-concern speech is involved, as the MSPB in Smith eventually assumes for the sake of argu-

219. Id. at 63. Smith was a "Management \& Program Analyst (Labor Relations Program Manager) in the Flight Standards Division of the Federal Aviation Administration's ("FAA") Administrative Services Branch in Atlanta." Id.

220. Id. at 78 .

221. Id.

222. Member Sapin dissented, but only on the holdings under the civil service provisions. She did not address the First Amendment claims. Id. at 90-98.

223. Mings v. Dep't of Justice, 813 F.2d 384, 387 (Fed.Cir.1987) (quoting Connick v. Myers, 461 U.S. 138, 146 (1983)).

224. Connick, 461 U.S. at 146. 
ment, ${ }^{225}$ a much more delicate balancing between employee First Amendment interests and governmental efficiency issues must be undertaken.226 By citing the Federal Circuit in Mings, the MSPB therefore compounds the twenty-year mistake by again undertaking the wrong balancing of interests.

The MSPB also makes two mistakes in discussing whether the filing of an equal employment opportunity ("EEO") complaint is speech on a matter of public concern. Although the MSPB correctly recognizes that "a discussion regarding racial relations or discrimination is a matter of public concern entitled to the full protection of the First Amendment,"227 it cites to circuit court precedent for the proposition that the complaint has to be public, ${ }^{228}$ and that the filing of a discrimination claim is "personal in nature and generally related to [the employee's] own situation." 229

As to the MSPB's first point, in Givhan v. Western Line Consolidated School District, ${ }^{230}$ the Court held that a racial discrimination complaint made in a private conversation could still be on a matter of public concern. This principle was later reaffirmed by the Court in Rankin $v$. McPherson, ${ }^{231}$ in which private, negative comments about the assassination attempt on President Reagan were found to touch on matters of public concern. ${ }^{232}$ Indeed, a closer look at the Eleventh Circuit opinion, cited by the Smith majority, shows that the Eleventh Circuit understood that "a court cannot determine that an utterance is not a matter of public concern solely because the employee does not air the concerns to the public," 233 though an employee's at-

225. Smith, 106 M.S.P.R. at 80.

226. Brown v. Dep't of Transp., FAA, 735 F.2d 543, 548 (Fed. Cir. 1984).

227. Smith, 106 M.S.P.R. at 79 (citing Connick, 461 U.S. at 148 n.8 (speech protesting racial discrimination is "inherently of public concern")).

228. Id. (quoting Watkins v. Bowden, 105 F.3d 1344, 1353 (11th Cir.1997) ("In determining whether an employee's speech relates to a matter of public concern or to his own private interest, courts also consider the employee's attempts to make the concern public and the employee's motivation in speaking.")).

229. Id. (citing Saulpaugh v. Monroe Cmty. Hosp, 4 F.3d 134, 143 (2d Cir.1993)).

230. 439 U.S. $410,415-16(1979)$.

231. 483 U.S. 378 (1987).

232. Id. at $386-87$.

233. Morgan v. Ford, 6 F.3d 750, 754 n.5 (11th Cir. 1993). See also Azzaro v. County of Allegheny, 110 F.3d 968, 978 (3d Cir. 1997) (en banc) ("П]f the content and circumstances of a private communication are such that the message conveyed would be relevant to the process of self-governance if disseminated to the community, that communication is public concern speech even though it occurred in a private context."). 
tempt at public disclosure may be relevant. However, in a situation where the speech concerns claims of racial discrimination, which are "inherently of public concern,"234 it is not clear how the fact that the claims were not publicly aired is dispositive.

Similarly, the MSPB's cursory conclusion that an EEO complaint is merely personal in nature indicates a foundational misunderstanding of the dual purposes of Title VII of the Civil Rights Act of $1964^{235}$ and similar federal and state antidiscrimination laws. Here, the MSPB is not alone in its misunderstanding of employment discrimination law, but is joined by the Second and Seventh Circuits in this error. ${ }^{236}$ The purpose of employment discrimination laws is both to make the individual whole from unlawful discrimination and to vindicate the public interest in eradicating employment discrimination from society as a whole. ${ }^{237}$ To say that an EEO complaint only serves the employee's personal purposes ignores the public interests vindicated by such laws and complaints filed by employees like Smith. ${ }^{238}$ This is not to say that the MSPB necessarily arrived at the wrong legal conclusion, but only that the

234. Connick v. Myers, 461 U.S. 138,148 n. 8 (1983).

235. 42 U.S.C. $\$ \S 2000 \mathrm{e}-2000 \mathrm{e}-17(2000)$.

236. Saulpaugh v. Monroe Community Hosp., 4 F.3d 134, 143 (2d Cir. 1993) (citing Ezekwo v. NYC Health \& Hospitals Corp., 940 F.2d 775, 781 (2d Cir. 1991)); Yatvin v. Madison Metro. School Dist., 840 F.2d 412, 420 (7th Cir. 1988)). The better view is that espoused by the en banc Third Circuit in Azzaro: "In rejecting this notion [that discrimination must be systemic to be of a public concern], we do not suggest that all public employee complaints about sexual harassment are matters of public concern. We do believe, however, that under all of the surrounding circumstances, Azzaro's reports address a matter of public concern even though they referred to a single incident." Azzaro, 110 F.3d at 980; see also Campbell v. Galloway, 483 F.3d 258, 269 (4th Cir. 2007) ("Complaints of sexual harassment are not per se matters of public concern; whether such complaints are in any given case depends on the content, form and context of the complaint. Applying that standard to this case and viewing the complaints in the light most favorable to Campbell, we conclude that Campbell's complaints about sexual discrimination do amount to matters of public concern.").

237. See Franks v. Bowman Transp. Co., 424 U.S. 747, 771 (1976) ("[T]he denial of seniority relief to victims of illegal racial discrimination in hiring is permissible 'only for reasons which, if applied generally, would not frustrate the central statutory purposes of eradicating discrimination throughout the economy and making persons whole for injuries suffered through past discrimination.'” (quoting Albemarle Paper Co. v. Moody, 422 U.S. 405, 421 (1975) (emphasis added))); see also EEOC v. Waffle House, Inc., 534 U.S. 279, 292 (2002) (recognizing that the EEOC has the statutory authority to vindicate both the private and public interests served by Title VII).

238. See Albemarle, 422 U.S. at 421 (establishing eradication of discrimination throughout the economy as one of the central statutory purposes of Title VII). 
MSPB lacks the necessary tools to undertake the sensitive balancing of relevant interests that need to be considered in cases such as Smith. As a result, federal employees' First Amendment rights to free speech are unnecessarily sacrificed.

Perhaps the lack of neutrality and competency on the part of the MSPB would be bearable and less worrisome if there were meaningful judicial review by an Article III court. Unfortunately, as the next section illustrates, that is not the case.

\section{The Federal Circuit Experience Handling First Amendment Pickering Claims}

As noted above, the Federal Circuit hears appeals from the MSPB concerning adverse employment decisions. ${ }^{239}$ There does not appear to be much disagreement in how First Amendment Pickering free speech claims are handled by the MSPB as opposed to how they are treated by the Federal Circuit Court of Appeals. Indeed, in 2006, the MSPB reported that the Federal Circuit affirmed ninety-three percent of the MSPB's decisions. ${ }^{240}$ The most likely reason for this high affirmation rate is the highly deferential standard of review in such cases: "The decision of the MSPB must be affirmed unless we find it to be arbitrary, capricious, an abuse of discretion, or otherwise not in accordance with law; obtained without procedures required by law, rule, or regulation having been followed; or unsupported by substantial evidence." 241 In other words, this is in no way the type of review a First Amendment claim brought directly to a federal district court would receive if brought under Bivens or a $\$ 1983$ federal analogue. ${ }^{242}$

In fact, the First Amendment MSPB cases involving the free speech Pickering analysis for federal employees follows this overall pattern to the same degree. Every single Federal Circuit case that decided a First Amendment issue on the mer-

239. See Robert G. Vaughn, Ethics in Government and the Vision of Public Ser. vice, 58 GEO. WASH. L. REV. 417, 425 n.35 (1990) ("The United States Circuit Court of Appeals for the Federal Circuit exercises exclusive jurisdiction over most appeals of federal employees taken from personnel actions.") (citing 5 U.S.C. $\S$ 7703(b)(1), (d) (2006) and VAUGHN, supra note 11, at $\S 17.02[2], 17-14.1$ ). The MSPB has held this role since 1982. 5 U.S.C. $§ 7703$; Federal Court Improvement Act of 1982, 28 U.S.C. $\$ 1295$ (2000).

240. MSPB Performance and Accountability Report (PAR), supra note 177, at $5-6$.

241. Holland v. Dep't of Air Force, 31 F.3d 1118, 1120 (Fed. Cir. 1994) (citing 5 U.S.C. $\S 7703(\mathrm{c}))$.

242. See supra Part II.A; see infra IV.A. 
its found in favor of the government agency. ${ }^{243}$ This is not surprising from the perspective that " $[t]$ he opinions of the courts place great emphasis on hierarchy of command in defining government interests, including interests in efficiency."244 Overall, the last twenty-five years have witnessed the Federal Circuit uphold ten out of ten decisions for federal agency employers on the merits. ${ }^{245}$ Each of these cases found against the First Amendment rights of public employees or, in the alternative, declared that the court did not have jurisdiction over the First Amendment claim or that it was unnecessary to decide the constitutional claim because of the resolution of the civil service statutory cause of action.

Both of these latter two procedural methods of dismissing federal employee First Amendment claims also highlight the shortcomings of the MSPB/Federal Circuit administrative scheme. For instance, if the Federal Circuit overturns the MSPB and reinstates an employee who suffered an adverse employment decision based on civil service provisions, the court finds that it need not address the First Amendment claim at all. ${ }^{246}$ Although this is consistent with the Ashwander doctrine of constitutional avoidance, ${ }^{247}$ this approach cheapens the

243. Kohl v. U.S. Postal Service, 115 F. App'x 49 (Fed. Cir. 2004); Guise v. Dep't of Justice, 330 F.3d 1376 (Fed. Cir. 2003); Henry v. Dep't of Navy, 902 F.2d 949 (Fed. Cir. 1990); Banks v. Garrett, 901 F.2d 1084 (Fed. Cir. 1990); England v. Dep't of Treasury, 889 F.2d 1100 (Table) (Fed. Cir. 1989); Woodward v. United States, 871 F.2d 1068 (Fed Cir. 1989); Mings v. Dep't of Justice, 813 F.2d 384 (Fed. Cir. 1987); Stanek v. Dep't of Transp., 805 F.2d 1572 (Fed. Cir. 1986); Fiorillo v. U.S. Dep't of Justice, Bureau of Prisons, 795 F.2d 1544 (Fed. Cir. 1986); Brown v. Dep't of Transp., FAA, 735 F.2d 543 (Fed. Cir. 1984). There were an additional eight cases going back to 1969 that discuss First Amendment rights of federal employees, but because these cases were not decided by the Federal Circuit they were not considered in this analysis.

244. Vaughn, supra note 239 (also discussing cases outside of the First Amend. ment).

245. Neither the Chambers nor Stone case, discussed in detail above, are part of this analysis as the Stone decision was not appealed and the Chambers decision is pending appeal on non-First Amendment issues. See Smith v. Dep't of Transp., 106 M.S.P.R. 59 (2007); Chambers v. Dep't of Interior, 103 M.S.P.R. 375 (2006).

246. See, e.g., Holland v. Dep't of Air Force, 31 F.3d 1118, 1122 (Fed. Cir. 1994) (because agency personnel decision was not sustained under civil service provisions, "we do not reach the question whether the cited Air Force regulations, if they supported Holland's demotion based on his statements of belief, would run afoul of the First Amendment").

247. See Pamela S. Karlan, The Paradoxical Structure of Constitutional Litigation, 75 FORDHAM L. REV. 1913, 1929 n.90 (2007) (citing Ashwander v. TVA, 297 U.S. 288, 347 (1936) (Brandeis, J., concurring)) ("Under the so-called 'Ashwander doctrine,' the Supreme Court prefers that cases be decided on statutory rather than constitutional grounds when possible."). 
value of constitutional rights and the importance of constitutional adjudication.

Perhaps even more problematic is the situation where, because the underlying prohibited personnel action does not amount to a covered employment decision under the civil service laws, the Federal Circuit finds that the MSPB did not have proper jurisdiction over the claim and thus, the court cannot hear the claim either. ${ }^{248}$ Yet, if the federal employee initially sought to bring the action as a Bivens-type First Amendment claim, it would certainly fail under Bush v. Lucas. ${ }^{249}$ In other words, in cases the MSPB lacks jurisdiction, the employee is left without a First Amendment claim at all, let alone a meaningful or effective one. ${ }^{250}$

The high affirmation rate is to be expected for at least one other reason. As a general matter, federal courts of appeal usually defer to the expert agencies that have been given broad discretion in interpreting the statutes over which they have authority. ${ }^{251}$ This leads to the deferential standard of review cited to above. ${ }^{252}$ Yet, the affirmation rate of the MSPB is much higher than the rates for similar agency adjudicatory bodies like the National Labor Relations Board, the Patent and Trademark Office, or the Immigration and Naturalization Service. $^{253}$ Something else is afoot. Although hard to prove, it

248. Manning v. Merit Sys. Prot. Bd., 742 F.2d 1424 (Fed Cir. 1984) (in performance review reprisal cases, upholding basic principle that MSPB jurisdiction extends only to those actions made appealable by law, rule, or regulation and plaintiff's First Amendment claim was not therefore appealable); Rosano v. Dep't of the Navy, 699 F.2d 1315, 1318-20 (Fed. Cir. 1983) (same outcome with regard to federal employee health benefits plan claim). This is so even though Bush $v$. Lucas stated, misleadingly in retrospect, that "[c]onstitutional challenges to agency action, such as the First Amendment claims raised by petitioner, are fully cognizable within this [regulatory] system." Bush v. Lucas, 462 U.S. 367, 386 (1983).

249. See supra Part II.C.

250. The Federal Circuit's unhelpful response to this state of affairs is that, "we see no support in Bush for the contention that there must be an administra. tive remedy for every constitutional violation alleged by a federal employee." Manning, 742 F.2d at 1429. So much for a "comprehensive" administrative scheme.

251. This is sometimes referred to as "Cheuron deference." See Patrick M. Garry, Accommodating The Administrative State: The Interrelationship Between The Chevron And Nondelegation Doctrines, 38 ARIZ. ST. L.J. 921, 941 (2006) ("Cheuron[, 467 U.S. 837 (1984),] deference means that the courts must sanction any rational interpretation the agency makes. This rule of deference prevails even if a court would have reached a different conclusion had it considered the issue de novo.").

252. See supra note 155 and accompanying text; supra note 241.

253. See Peter H. Schuck \& E. Donald Elliott, To the Chevron Station: An Em- 
might have to do with the way MSPB members are appointed and their lack of competence as either non-attorneys or adjudicators who lack familiarity with the ins-and-outs of the Pickering framework. ${ }^{254}$ With time comes experience, but the affirmation rate suggests that the Federal Circuit is none too eager to disagree with the MSPB on federal personnel manners. In addition, time does not provide much experience given that one Westlaw law inquiry establishes that the Federal Circuit heard a total of only seventy-nine First Amendment cases in its twenty-five year existence, ${ }^{255}$ but heard approximately 5741 patent cases during that same period. ${ }^{256}$

In all, the Federal Circuit's track record of only finding for agencies on federal employees' First Amendment Pickering claims does not inspire confidence, suggests some political bias in the system toward agencies, and highlights the relative lack of experience of the court in these types of constitutional matters. As a result, the only Article III review that these claims are receiving is not meaningful or effective under any definition.

\section{Revitalizing the First Amendment PICKERING Rights OF FEDERAL EMPLOYEES}

The first thing that strikes one who studies Federal Circuit and MSPB First Amendment Pickering cases is their sheer paucity. Some of this lack of cases is no doubt due to employees bringing similar claims under the Whistleblower Protection

pirical Study of Federal Administrative Law, 1990 DUKE L.J. 984, 1013-22 (1990) (finding that from 1984 to 1985 , federal circuit courts affirmed in full seventy-five percent of NLRB orders, eighty-three percent of Immigration and Naturalization Service orders, eighty-one percent of Patent and Trademark Office orders, and ninety percent of MSPB orders). Since 1985, the affirmance rate for MSPB orders has only increased. See supra note 240 and accompanying text.

254. Alternatively, it might be attributable to the fact that, "[m]any of [the Federal Circuit's] non-precedential opinions are in pro se appeals by federal employees from decisions of the Merit Systems Protection Board. Because these cases are often poorly briefed, it is easy to miss potentially important legal issues." Penelope Pether, Sorcerers, Not Apprentices: How Judicial Clerks And Staff Attorneys Impoverish U.S. Law, 39 ARIZ. ST. L.J. 1, 16 (2007) (citing ROBERT TIMOTHY REAGAN ET AL., FED. JUDICIAL CTR., Citing Unpublished Opinions in Federal Appeals 75 app. (2005) (quoting Judge JF-2)).

255. There were actually 142 results, but the Court of Claims, the Federal Circuit predecessor, heard the other cases prior to 1982.

256. The queries run in the CTAF (Westlaw Federal Circuit database) were: “ 'first amendment' \% patent! copyright! trademark!" and "patent! and da (after 1982)" respectively. 
Act ("WPA"), but the comparison between similar claims brought by state employees under $\S 1983$ tells a different story. Whereas there are approximately twenty MSPB decisions and ten Federal Circuit decisions in the last twenty-five years on First Amendment Pickering claims, there are literally thousands, if not more, state and local First Amendment claims. ${ }^{257}$

The difference cannot only be attributed to the availability of WPA claims for at least two reasons. First, many state and local employees who have whistleblower statutory claims, also bring First Amendment claims. ${ }^{258}$ Second, the available empirical evidence suggests that federal employees who bring claims under the WPA are highly unsuccessful, ${ }^{259}$ so unsuccessful that Congress is currently considering enhancements to employee protections under the WPA. ${ }^{260}$

The better answer appears to be that federal employees are not bringing First Amendment claims because there is no reason to think that such claims have any chance of success. Who can blame federal employees for this assumption? When every single MSPB and Federal Circuit First Amendment Pickering case decided on the merits comes out in favor of the employer, employees and their attorneys learn very quickly that these adjudicators lack the requisite neutral competence and that these types of claims are simply a waste of time and money. ${ }^{261}$ All this leads to a call, in the next two subsections, for a revitalization of federal employee First Amendment Pickering claims, either under Bivens or an extension of $\S 1983$ to violations under color of federal law.

257. See supra note 13 and accompanying text.

258. For example, state and local employees in New York and Pennsylvania may bring state statutory whistleblower claims. See N.Y. CIVIL SERVICE LAW $\S$ 75-b (McKinney 2006); 43 PA. ConS. STA'T. §§ 1421-28 (2005).

259. See supra note 14 and accompanying text.

260. See supra note 167 and accompanying text.

261. Federal employees may instead prefer to proceed under a negotiated grievance procedure rather than proceeding through the MSPB. See Don Cheney, Postal Employees Should Think Twice Before Appealing Case to MSPB, POSTALREPORTER.COM BLOG, Feb. 12, 2007, available at http://www.postalreporter.com/news/2007/02/12/postal-employees-should-think-twice-before-

appealing-case-to-mspb ("Kenneth Jones vs. US Postal Service[, 216 F. App'x 986 (Fed. Cir. 2007),] illustrates why postal employees should think twice before appealing their discipline to the Merit Systems Protection Board. They have a bet. ter chance of success in the grievance procedure.") (last visited Aug. 3, 2008). Whether arbitrators will be better able to decide these Pickering cases in a neutrally competent way is an interesting question, but beyond the scope of this article. 


\section{A. Bring Bivens Back for Federal Employees' First Amendment Claims}

The purpose of this section is not to argue that Bush v. Lucas was wrongly decided in 1982 . Indeed, it would be hard to do so considering that it was a unanimous decision, with the author of Bivens himself, Justice Brennan, joining the opinion. ${ }^{262}$ Rather than attack the logic of Bush, this section argues that its underlying assumptions are no longer valid twenty-five years after it was decided.

Most specifically and to the point, federal employees are not able to receive a meaningful or effective remedy for their First Amendment claims under the CSRA of 1978.263 Empirical analyses do not lie and the lack of any success of such claims at the MSPB or federal appellate level explains why there is little First Amendment activity. It is certainly not because the federal civil service has become magically immune from everyday employment disputes. Instead, employees are turning to the equally deficient WPA, ${ }^{264}$ swallowing hard and doing nothing, ${ }^{265}$ or just leaving federal service and taking their talents elsewhere. ${ }^{266}$

If the CSRA of 1978 were providing a meaningful, effective remedy for the federal employees' First Amendment claims, there would be every reason to argue that the Bivens remedy in

262. See supra note 91 and accompanying text.

263. As argued previously, "meaningful remedies" appears to be the touchstone for determining whether a statutory alternative is constitutionally adequate for vindicating individuals' constitutional rights. See Bush v. Lucas, 462 U.S. 367, 386 (1983) ("As the record in this case demonstrates, the Government's comprehensive scheme is costly to administer, but it provides meaningful remedies for employees who may have been unfairly disciplined for making critical comments about their agencies."); id. at 390 (Marshall, J., concurring) ("[A] different case would be presented if Congress had not created a comprehensive scheme . . . that affords a remedy that is substantially as effective as a damage action.").

264. See supra note 14 and accompanying text.

265. This conclusion is supported by analysis of the First Amendment cases that the MSPB has decided. There have only been four such cases in the 1990s and 2000 s, illustrating a belief among federal employees and their representatives that they cannot receive meaningful redress from the MSPB for their First Amendment free speech claims. See supra note 188 and accompanying text.

266. Statement of Senator Daniel K. Akaka, Subcommittee on the Oversight of Government Management, the Federal Workforce, and the District of Columbia, Building the 21st Century Federal Workforce: Assessing Progress in Human Capital Management (July 20, 2004), http://akaka.senate.gov/publicl index.cfm?FuseAction $=$ speeches.home\&month $=7 \&$ year $=2004 \&$ release_id $=762$ ("We may be winning the hearts and minds of Americans seeking employment with the federal government, but we are still losing the talent war."). 
this context is not necessary. Unfortunately, that is just not the case. Since the Bush case, there has not been one instance of a Pickering analysis being applied by the MSPB or Federal Circuit in which the employee comes out on top. ${ }^{267}$ This is truly remarkable.

Nor is there reason to believe that there should not be a Bivens claim because of "special factors counseling hesitation." When Bush was decided, the thought was that Congress spent a hundred years putting together a comprehensive civil service system that would attract and keep the best and brightest federal employees. ${ }^{268}$ It was universally thought that Congress had the institutional competence to formulate a civil service system that would prevent partisanship and provide the best employees for the national government. ${ }^{269}$

A claim is not being made that the CSRA of 1978 has not worked at all. Indeed, outside of the First Amendment context, there is every reason to believe that the system is working as well as one might expect. A claim is being made, however, that there is no further reason to defer to the institutional competence of Congress in not recognizing a direct constitutional remedy for First Amendment free speech claims for federal employees. For these claims at least, Congress has shown itself singularly incompetent in trying to protect the constitutional rights of federal employees. At the end of the day, it does not matter whether this is because the MSPB is not neutral enough, ${ }^{270}$ not competent enough, ${ }^{271}$ or not experienced

267. The concept of the "inexorable zero" in disparate impact law under Title VII of the Civil Rights Act of 1964 comes to mind here. In pattern and practice group employment discrimination cases, courts rely on statistics to determine whether an employer has a standard operating procedure of discriminating against certain protected groups, like minorities. See Intern. Bhd. of Teamsters v. United States, 431 U.S. 324 (1977). In such cases, when no minorities have been hired at all by the employer, "fine tuning of the statistics [do not] obscure[] the glaring absence of minority [employees].... [T] he company's inability to rebut the inference of discrimination came not from a misuse of statistics but from 'the inexorable zero." Id. at 342 n.23.

268. See Bush v. Lucas, 462 U.S. 367, 389 (1983) ("Congress is in a far better position than a court to evaluate the impact of a new species of litigation between federal employees on the efficiency of the civil service.").

269. Id. ("Congress has a special interest in informing itself about the efficiency and morale of the Executive Branch. In the past it has demonstrated its awareness that lower-level government employees are a valuable source of information, and that supervisors might improperly attempt to curtail their subordinates' freedom of expression.").

270. Compelling evidence of partisan divides in other politically-appointed, adjudicative agencies does appear to exist. See Ronald Turner, Ideological Voting on the National Labor Relations Board, 8 U. PA. J. LAB. \& EMP. L. 707, 711 (2006) 
enough with these types of claims. ${ }^{272}$ What matters is that the constitutional rights of federal employees are being ignored and sacrificed at an alarming rate.

The only real solution is to recognize that when it comes to First Amendment federal employee Pickering rights, Bivens remedies provide the best alternative of all the options. Under Bivens, federal employees will be able to take their free speech claims directly to an independent Article III court, which has much experience adjudicating such claims under $\S 1983 .{ }^{273}$ Applying standards similar to those used under $\S 1983$, federal court adjudication once again will assure a neutrally competent arbiter of federal employees' constitutional rights. Moreover, such claims, with the ability to hold individual federal supervisors and managers directly liable for damages, may lead to a greater deterrent effect than is currently possible under the existing regime. ${ }^{274}$

There may be some who claim that this proposal does nothing less than open the proverbial "floodgates of litigation." But the second Justice Harlan answered this criticism well in his concurring opinion in Bivens:

[T] he question appears to be how Fourth Amendment interests rank on a scale of social values compared with, for example, the interests of stockholders defrauded by misleading proxies. Judicial resources, I am well aware, are increasingly scarce these days. Nonetheless, when we automatically close the courthouse door solely on this basis [of inundating courts with Fourth Amendment claims], we implicitly express a value judgment on the comparative importance of classes of legally protected interests. ${ }^{275}$

("The only claim made in this Article is that ideology has been a persistent and, in many instances, a vote-predictive factor when the [National Labor Relations] Board decides certain legal issues.").

271. See supra note 217 and accompanying text.

272. See supra note 186 and accompanying text.

273. Wilkie v. Robbins, 127 S. Ct. 2588, 2615-16 (2007) (Ginsburg, J., concurring in part and dissenting in part) ("Because we have no reason to believe that state employees are any more or less respectful of Fifth Amendment rights than federal agents, $\S 1983$ provides a controlled experiment.").

274. See Louise Weinberg, The Monroe Mystery Solved: Beyond The "Unhappy History" Theory Of Civil Rights Litigation, 1991 B.Y.U. L. REV. 737, 762-63 ("An action against an individual may have greater deterrence value, especially since punitive damages are available under Bivens.").

275. Wilkie, $127 \mathrm{~S}$. Ct. at 2613 (Ginsburg, J., concurring in part and dissenting in part) (quoting Bivens, 403 U.S. 388, 410-411 (1971) (Harlan, J., concurring) (citation omitted)). 
In short, "[t]he 'floodgates' argument . . . has been rehearsed and rejected before." 276 In any event, the statistics of $\S 1983$ cases just do not bear out that such a flood would arise from the recognition of a Bivens claim in this context. ${ }^{277}$ Even with a much larger number of state and local employees in this country, ${ }^{278}$ federal courts still adequately handle existing $\S 1983$ causes of action. ${ }^{279}$ It is hard to believe that another three million federal employees, about one-sixth the number of their state and local counterparts, will cause irreconcilable problems for the courts.

In short, it is time to face the fact that the civil service scheme does not adequately vindicate constitutional First Amendment Pickering rights of federal employees. Therefore, it is time to permit Bivens claims in this context.

\section{B. The Alternative: Section 1983 for Federal Employees}

There is, of course, another way to provide more effective constitutional protection for federal employees: Congress could provide a statutory-based, $\S 1983$-like action for federal employees. ${ }^{280}$ All that it would take would be for Congress to pass a Civil Rights Act that would either add "under color ... of any federal or State law" to $\S 1983$ or propose a new statute with "under color ... of any State law" substituted with "under color . . . of any federal law."281 After that, all other principles of municipal liability, including sovereign and qualified immunity, under $\S 1983$, would apply equally to federal officers' vio-

276. Id.

277. Schwab \& Eisenberg, supra note 12, at 643 (concluding there has not been an uncontrolled mushrooming of cases in the federal courts under Section 1983).

278. There are about three million federal employees and eighteen million state and local employees. West \& Durant, supra note 171 ; U.S. DEP'T OF COMMERCE, U.S. CENSUS BUREAU, STATISTICAL ABSTRACT OF THE UNITED STATES 298 (2004-2005) (Table No. 453) (figure from 2002).

279. Schwab \& Eisenberg, supra note 12, at 642-43 ("Both national data published by the Administrative Office of the United States Courts and our findings about a key federal district suggest that the image of a civil rights litigation explosion is overstated and borders on myth.").

280. Bivens v. Six Unknown Named Agents of Federal Bureau of Narcotics, 403 U.S. 388, 427-28 (1971) (Black, J., dissenting) ("If it wanted to do so, Congress could, of course, create a remedy against federal officials who violate the Fourth Amendment in the performance of their duties."). See also Seamon, supra note 33 , at $758-59$.

281. This approach appears to be similar to what Justice Ginsburg suggests in her Wilkie dissent. Wilkie, $127 \mathrm{~S}$. Ct. at 2618 (Ginsburg, J., concurring in part and dissenting in part) ("If Congress wishes to codify and further define the Bivens remedy, it may do so at anytime."). 
lations of the Constitution. ${ }^{282}$ Compensatory and punitive damages would be available against individual federal government officials accused of violating the Constitution. ${ }^{283}$

This legislative approach has the advantage of being less problematic from a separation of powers standpoint and arguably would place the power to create a remedy in the branch of government where it rightfully belongs. ${ }^{284}$ It suffers from one glaring shortcoming, however, at least in the broad form proposed. ${ }^{285}$ It would not just apply to federal employees and the First Amendment, as the proposed Bivens solution would, but would apply to all violations of the Constitution by all federal officials. If Congress felt comfortable doing that, it would have done so a long time ago. In the end, it seems impracticable in the current political environment that Congress would act to codify the Bivens remedy.

\section{CONCLUSION}

There has been little controversy over the substitution of the civil service regime for First Amendment litigation as a re-

282. See supra Part II.A. See also Butz v. Economou, 438 U.S. 478, 500 (1978) (" $[\mathrm{I}] \mathrm{n}$ the absence of congressional direction to the contrary, there is no basis for according to federal officials a higher degree of immunity from liability when sued for a constitutional infringement as authorized by Bivens than is accorded state officials when sued for the identical violation under $\S 1983 . ")$.

283. See supra note 69 and accompanying text. Damage actions would not be permitted against the United States because the United States has not waived sovereign immunity for constitutional violations. See supra note 79.

284. Newman, supra note 100 , at $472-73$ (maintaining that diminished state of Bivens jurisprudence points to a trend that reflects the adoption of the same separation of powers concerns of the Bivens dissenters). But see George D. Brown, Letting Statutory Tails Wag Constitutional Dogs-Have the Bivens Dissenters Prevailed?, 64 IND. L.J. 263, 294-95 (1989) (maintaining that constitutional nature of Bivens should mean less deference to Congress); Gene R. Nichol, Bivens, Chilicky, and Constitutional Damages Claims, 75 VA. L. REV. 1117, 1153 (1989) (arguing that implying constitutional damage remedies is an indispensable com. ponent of constitutional oversight).

285. Professor Seamon has explored the possibility of a narrower Section 1983 revision which would apply to actions taken by federal agents under the color of the federal law with regard to torture claims. Seamon, supra note 33, at 759 ("A narrower version would create a cause of action against any person acting under color of federal law who 'subjects, or causes to be subjected,' another person to 'torture,' a term that would be defined-either in the same statute or by reference to one of the existing statutory definitions of the term."). Similarly, Congress could pass a narrower law which would create a cause of action against federal officials and entities that interfere with the freedom of expression of federal employees. I would think the likelihood of such a bill ever being enacted, however, is very slim. 
sult of the Supreme Court's decision in Bush v. Lucas. ${ }^{286}$ But the emperor has no clothes. Not only do federal civil service administrative proceedings not have all the due process and remedial bells and whistles that we have come to expect in litigation before an independent Article III federal court, but federal employees have also, by and large, ceased to bring First Amendment claims under this administrative scheme.

Federal employees no longer believe that they can receive substantive justice for their First Amendment Pickering rights under the Civil Service Reform Act of 1978. Indeed, this Article's analysis of MSPB and Federal Circuit decisions involving federal employees' claims has been undertaken to answer one crucial question: are these agencies neutrally competent to protect federal employees' First Amendment rights?287 The answer, based on a review of case law, is a resounding no. Not $a$ single published case, at either the administrative or appellate level, has upheld the First Amendment rights of a federal employee on the merits under the Pickering analysis.

The solution to this inequitable state of affairs can only be accomplished by a reinvigoration of federal employees' First Amendment free speech rights through overturning the decision in Bush v. Lucas and implying a direct Bivens remedy. Alternatively, $\S 1983$ could be expanded by Congress to provide a statutory basis for federal employees to bring constitutional tort claims against federal agents for violating their constitutional rights under color of federal law. Only by taking one of these necessary steps can the public be "assured that federal officials w[ill] be subject to the same constraints as state officials in dealing with the fundamental rights of the people who dwell in this land."288

286. But see Joan Steinman, Backing Off Bivens and the Ramifications of this Retreat for the Vindication of First Amendment Rights, 83 MICH. L. REV. 269, 270 (1984) (predicting presciently in 1984 that Bush and other Bivens cases could "in. crease the risk that first amendment rights will be under-enforceable, even unconstitutionally so").

287. This is crucial because "[t]he very essence of civil liberty certainly consists in the right of every individual to claim the protection of the laws, whenever he receives an injury." Marbury v. Madison, 1 Cranch 137, 163 (1803).

288. Wilkie v. Robbins, 127 S. Ct. 2588, 2618 (2007) (Ginsburg, J., concurring in part and dissenting in part). 